JEL Classification: E58, G01, G21, G28, H81

Keywords: systemic risk, macroprudential policies, banks, risk taking

\title{
Effects of Macroprudential Policy on Systemic Risk and Bank Risk Taking*
}

Alin-Marius ANDRIEȘ - Alexandru loan Cuza University of lasi, Romania (alin.andries@uaic.ro)
Florentina MELNIC - Alexandru loan Cuza University of lasi, Romania
(florentina_iesanmuntean@yahoo.com) corresponding author

Simona NISTOR - Babes - Bolyai University of Cluj Napoca, Romania (simona.mutu@econ.ubbcluj.ro)

\section{Abstract}

Using an international sample of 95 banks from 21 European and North American countries spanning from 2008 to 2014, this paper assesses the effectiveness of a large set of general and housing macro-prudential policies in controlling banks' systemic importance and risk-taking incentives. Empirical findings indicate that tightening the general capital requirements, sector specific capital buffers, along with housing countercyclical capital requirements and Debt-Service-to-Income lending criteria significantly reduce banks' contribution to systemic risk and their individual risk-taking. A similar effect has been obtained for loosening real estate loans loss provisioning. Furthermore, the nexus between macroprudential policies and banks' risk is shaped through several channels like bank size, the share of foreign bank assets, banking sector competition and the independence of supervisory authority.

\section{Introduction}

The 2008 global financial crisis forced central authorities and policymakers to reconsider the regulatory framework and their primarily objectives. In the pre-crisis years the capacity of the authorities to mitigate financial vulnerabilities was limited as their main objectives were price stability and economic activity (from a macroeconomic perspective) and idiosyncratic risk (from a microeconomic perspective) (IMF, 2013). The post-crisis events determined central authorities to rely more on macroprudential policies in order to reduce systemic risk, increase financial stability and build a safer financial system that could reduce the probability of future crises. According to the literature (see e.g. Lim et al., 2011; Claessens et al., 2013; Aydinbas et al., 2015; Cerutti et al., 2017b), the main objective of macroprudential policy is to limit the financial risk that affects the whole system (systemic risk). As noted by Cerutti et al. (2017b) macroprudential policy seeks to increase the resilience of financial system to shocks, limit the build-up of vulnerabilities over time, control the structural vulnerabilities that could rise from inter-linkages and control the ,too-big-to-fail” institutions.

Macroprudential policy complements microprudential measures and interacts

\footnotetext{
* This work was supported by a grant of Ministery of Research and Innovation, CNCS - UEFISCDI, project number PN-III-P1-1.1-TE-2016-1855, within PNCDI III
}

The online appendix is available at: http://journal.fsv.cuni.cz/mag/article/show/id/1408 
with other types of tools, especially monetary policy (Aydinbas et al., 2015). Microprudential policy aims to limit the distress at individual institutions, while macroprudential policy focuses on financial system-wide distress. Both types of policies have to be implemented in a coordinated way, as individual institutions play an important role in the build-up and spread of systemic risk and the implementation of macroprudential policies should take into consideration their impact on individual institutions. Therefore, these policies are highly complementary, controlling the contribution to systemic risk of financial institutions. To limit systemic vulnerabilities and to achieve financial stability, macroprudential policy has to be supported by strong supervision and enforcement and filled by suited policies, such as monetary policy, fiscal and structural policies, competition policy, as well as crisis management and resolution policies (IMF, 2013).

The low monetary policy interest rates in the period prior to the crisis allowed banks to take on more risk, softening the lending conditions for all categories of borrowers (Maddaloni and Peydro, 2013). To transfer the additional assumed credit risk banks resorted to Credit Default Swaps and Collateralized Loan Obligations, actually posing greater systemic risk effects (Nijskens and Wagner, 2011).

The main instruments that can be used to mitigate excessive credit growth and leverage are: countercyclical capital buffer, sector specific requirements, loan-tovalue caps, loan-to-income caps, and, debt service-to-income caps (ESRB, 2014). If the economy is threatened by liquidity crisis, macroprudential policy can limit the banking vulnerabilities through taxes on noncore bank liabilities or on FXdenominated bank liabilities (these instruments can limit the banking loan growth indirectly). The loan growth can also be limited by altering the incentives of using bank-capital oriented tools, such as counter-cyclical capital requirements, forwardlooking provisioning and leverage cap. Another source of systemic risk is given by the status of 'too-big-to-fail' institutions that leads to misaligned incentives and moral hazard. The measures used to control this risk can be capital-based (systemic risk buffer, additional own funds and conservation buffer requirements) and liquidity-based.

Thus, macroprudential policy has two main objectives: to limit the build-up of systemic risk (time dimension) and to increase the resilience of financial system to future shocks (cross-sectional dimension). The instruments used can be creditrelated, liquidity-related and capital-related (Aydinbas et al., 2015). There is not a general accepted mix of instruments, these being adopted based on individual macroeconomic conditions: source of risk, financial development, type of exchange regime and the degree of international financial integration (Lim et al., 2011; Claessens et al., 2013).

In this paper, we assess whether macroprudential policies implemented at the country level have a significant impact on banks' contribution to systemic risk, as well as on their level of risk-taking. In a first step, we estimate banks' systemic importance employing the Conditional Value at Risk (CoVaR) methodology developed in Adrian and Brunnermeier (2016) and the Marginal Expected Shortfall 
(MES) methodology proposed by Acharya et al. (2017). ${ }^{1}$ In addition, we determine the level of bank risk-taking by using the Value at Risk (VaR) methodology and the Distance to Default (DTD).

In a second step, we analyze in a panel that includes 95 banks the impact of macroprudential policies on banks' systemic importance and risk-taking. We consider a large set of general and housing (real estate) policies implemented by 21 countries from Europe and North America during 2008 to 2014. The general macroprudential policies include capital requirements, sector specific capital buffers and reserve requirements on foreign and local currency denominated accounts. The housing macroprudential tools cover countercyclical capital requirements, loan loss provisioning, Debt-Service-to-Income (DSTI) lending criteria and risk weights on housing loans.

Overall, empirical findings indicate that tightening general capital requirements, sector specific capital buffers, along with housing countercyclical capital requirements and DSTI lending criteria can significantly reduce banks' systemic importance and also their individual risk-taking. For real estate loans loss provisioning we find a negative impact, tighter rules enhancing the level of risk. Furthermore, the nexus between macroprudential policies and banks' risk is shaped through several channels like bank size, the level of foreign bank assets, banking sector competition and the independence of supervisory authority.

This paper aims to contribute to the existing literature on systemic risk and macroprudential policies. First, we contribute to the literature on systemic risk determinants by considering a large set of general and housing macroprudential tools implemented by supervisory authorities in order to increase the resilience of the banking sector during crisis. A number of studies argue that excessive risk-taking can be restrained through more stringent prudential measures on either supply side (e.g. bank capital) or demand side (e.g. loan-to-value ratios) (Maddaloni and Peydro, 2013). However, regarding the impact of prudential policies on systemic risk there is little empirical evidence. Therefore, we investigate the macroprudential policies' impact on both individual risk-taking and on banks' contribution to systemic risk. A macroprudential policy tool can be effective in controlling banks' individual risk but mislead the financial contagion effects among the system.

Second, we extend the channels through which macroprudential policies could influence banks' systemic importance and their risk-taking behavior. We provide empirical evidence that the contribution to systemic risk of large banks can be decreased through higher reserve requirements on accounts denominated in foreign and local currencies and higher risk-weights applied to housing loans. The resilience of financial institutions from banking systems that hold important shares of foreign assets can be enhanced by loosening the reserve requirements and the countercyclical capital requirements. In case of less competitive banking markets, lower reserve requirements on domestic currency denominated accounts, lower countercyclical capital requirements and relaxed DSTI lending criteria are efficient in controlling systemic risk. In countries with higher degree of independence of supervisory

\footnotetext{
${ }^{1} \mathrm{CoVaR}$ accounts for time-varying contagion spillovers from a particular bank to the system (contribution to systemic risk), while MES considers the time-varying contagion effects from the system to a particular bank (exposure to systemic risk).
} 
authority, regulators should tighten the general capital requirements, but reduce the sector specific and countercyclical buffers to enhance the stability of the banking sector.

The current study differs from previous literature regarding the effectiveness of macroprudential policy in terms of instruments considered and channels through which these tools could influence banks' risk. It is related with the study of Bluhm and Krahnen, (2014), but however their paper studied only the impact of two macroprudential instruments (systemic capital requirements and systemic risk charges) on individual banks' contribution to systemic risk. In addition to the previous literature we use different market-based measures in order to quantify systemic risk (banks' systemic contribution defined through CoVaR and banks' exposure to systemic risk estimated through MES) and individual risk-taking (VaR and DTD). Bluhm and Krahnen (2014), for example, measured systemic risk through SVaR and banks' systemic contribution through Shapley value. Our most important contribution is related to investigating the effects of the relationship among various determinants of systemic risk (banks' size, international activity, banking sector competitiveness and the degree of supervisory authority independence) and macroprudential instruments on financial stability.

The remainder of the paper is organized as follows: Section 2 summarizes the review of related literature. Section 3 presents the methodology. Section 4 describes the sample and data. Section 5 reports the empirical results. Section 6 concludes.

\section{Related Literature}

Microprudential policy, through ensuring the resilience of individual institutions, has an important contribution to the resilience of the entire banking system. However, it is not sufficient, due to the complexity of financial system, and needs to be complemented by macroprudential policy. Macroprudential policy takes into consideration the procyclicality of the financial system (e.g. countercyclical capital buffers), the contribution of financial institutions to systemic risk (e.g. SIFIs surcharges), the build-up of systemic risk in specific segments of the market (e.g. LTV ratio), the leverage in nonfinancial sectors (e.g. DSTI ratio) and systemic liquidity concerns (Osinski, et al., 2013).

In a 2013 report, IMF analyzed the number of countries that used macroprudential policies during 2000-2012 period, concluding that emerging economies used them more frequently than advanced economies, and well before the 2008 financial crisis (IMF, 2013). Claessens et al. (2013) argued in their study that emerging economies were four times more likely to use macroprudential policies than advanced economies before crisis, and 3.3 times after crisis, as advanced economies started to introduce more prudential measures. This can be explained by the fact that emerging economies are more exposed to external shocks (due to capital flows) and their financial systems are less developed and less liberalized, and hence there is a more frequent necessity to contain market failures.

An extensive literature assesses the effectiveness of macroprudential policy tools on different measures of financial vulnerability and stability, e.g. Lim et al. (2011), Claessens, et al. (2013), Akinci and Olmstead-Rumsey (2018), Vandenbussche et al. (2015), Cerutti et al. (2017b), Corrado and Schuler (2017) and Altunbas et al. (2018). The use of macroprudential policies before the financial crisis 
could have prevented the negative contagion spillovers (Van Oordt and Zhou, 2015). Dell'Ariccia et al. (2012) found that macroprudential policies can reduce the occurrence of credit booms and decrease the probability of booms bust.

Macroprudential capital-tools can reduce the probability of crises by enhancing resilience to shocks and reduce credit growth in the short-term, by increasing the costs of credit (Bridges et al., 2015; Noss and Toffano, 2016). This statement is confirmed, also, by the empirical studies, that sustain that macroprudential capital requirements reduce the default probabilities of individual banks and the probability of a systemic crisis by about 25\% (Gauthies et al., 2012). These results are in line with Bluhm and Krahnen (2014) findings, sustaining that an increase in capital requirements ratio decreases banks' contribution to systemic risk. Dagher et al. (2016) indicate that an optimal level of bank capital that would have prevented the majority of past crises is between 15 to 23 percent of risk-weighted assets, as better-capitalized banks can continue lending more easily during downturns.

Macroprudential liquidity-tools, mainly reserve requirements, have contradictory results regarding their impact on credit growth. A number of studies affirm that raising reserve requirements can moderate credit growth (Lim et al., 2011; Fungacova et al., 2016), while other studies mitigate for no or only a weakly significant impact (Bruno et al., 2016; Kuttner and Shim, 2016). Borrower linked tools, such as limits on LTV and DSTI ratios have been found to improve banking resilience by reducing the credit risk on new loans (Hallissey et al., 2014) and moderate lending growth (Lim et al., 2011; Akinci and Olmstead-Rumsey, 2018; Kuttner and Shim, 2016).

Claessens et al. (2013) highlight that macroprudential policies help in controlling banking system vulnerabilities (asset growth, leverage growth, noncore vs. core liabilities). As the recent financial crisis was triggered by high assets prices and excessive credit growth, a strand of literature assesses the macroprudential policies' efficiency in restraining their growth and adverse effects. Akinci and Olmstead-Rumsey (2018) analyses the effect of macroprudential policy on domestic bank credit growth, housing credit growth and real estate price inflation, concluding that after the 2008 global financial crisis, macroprudential tightening was associated with lower bank credit growth, housing credit growth and real estate price inflation. These results are confirmed by Cerutti et al. (2017a) and Cizel et al. (2016) which find that in two years after the implementation of macroprudential policies, bank credit growth declines by 7.7 percentage points relative to the counterfactual of no measure.

Considering the individual measures, Akinci and Olmstead-Rumsey (2018) found that capital requirements (both general and sector specific), loan-to-value caps and/or debt-to-income ratio are effective in reducing general credit, respectively, housing credit growth. These results are in line with the findings of Lim et al. (2011) regarding the LTV and DSTI measures, while IMF (2013) and Dimova et al. (2016) confirmed the results regarding the capital requirements and the LTV and DTI ratios for emerging countries. On the other hand, reserve requirements do not have a significant impact on credit growth in Akinci and Olmstead-Rumsey (2018), while Lim et al. (2011), IMF (2013) and Claessens et al. (2013) found that reserve requirements reduce credit growth and asset price inflation. If we refer to 
international banking and the effects of spillovers, macroprudential policies implemented by one country in order to limit domestic credit might play a role on the international bank lending and financial stability. Avdjilev et al. (2017) studied the effects of LTV limits and local currency reserve requirements for 16 banking systems and 53 counterparty countries from 2000 to 2014. They concluded that the tightening of both LTV limits and local currency reserve requirements are associated with an increase in international bank lending of banks headquartered abroad to borrowers in the country that implemented the respective measure. When enacted by a home country (banks' headquarter is in that country), such a tightening is transmitted abroad by international banks in the form of higher growth in lending to borrowers in other destinations.

Besides credit growth, there are also other measures of systemic risk, such as: systemic liquidity, leverage and capital flows. In order to control liquidity risk, Lim et al. (2011) show that limits on maturity mismatch are effective in reducing the wholesale funding (credit/deposit ratio). Corrado and Schuler (2017) argue that targeting the interbank financing through stricter liquidity measures (liquidity coverage ratio and net stable funding ratio) reduces the severity of a breakdown in interbank lending. Banks that have higher leverage ratios and larger fractions of interbank assets are considered more vulnerable and should hold more capital (Gauthies et al., 2012). Highly levered banks contributed more to systemic risk, also, in a study by Brunnermeier et al. (2012) on US bank holding companies. The effects of excessive leverage can be mitigated through caps on the DSTI and foreign currency lending, ceilings on credit growth, reserve requirements, countercyclical capital requirements and dynamic provisioning (Lim et al., 2011). These results are also confirmed by Claessens et al. (2013), who add, as a measure that reduces the leverage and asset growth during boom times the loan-to-value ratio.

Given these results, both academics and policymakers plead for banking regulation to include a macroprudential perspective (Hanson et al., 2011; Gauthies et al., 2012). Gauthies et al. (2012) and Vallascas and Keasey (2012) sustain the initiative to regulate bank's leverage.

\section{Methodology}

We assess the impact of macroprudential policies implemented by supervisory authorities on banks' systemic importance and risk-taking using a panel framework. First, we analyze the nexus between general and housing macroprudential measures and banks' risk. Second, in a difference-in-difference setting we estimate the effectiveness of the instruments across different types of financial institutions and banking markets. The sample includes 95 banks from 21 countries (Canada, Europe and USA) and the period accounts for 28 quarters during 2008-2014.

\subsection{The Impact of Macroprudential Measures on Systemic Risk}

To assess the impact of macroprudential policies on systemic risk the following regression is estimated via OLS Fixed Effects with country level clustered standard errors:

$$
\begin{gathered}
\text { Systemic Risk } k_{i j, t}=\beta_{0}+\boldsymbol{\beta}_{1} \times \text { Macroprudential Policies } i j, t-1+\Phi \times \text { Bank controls }_{i j, t-1} \\
+\Psi \times \text { Market \& Macro controls } s_{j, t-1}+\varphi_{i}+\mu_{j}+v_{t}+\varepsilon_{i j, t}
\end{gathered}
$$


The dependent variable is represented by bank i's from country $\mathrm{j}$ contribution to systemic risk in quarter $\mathrm{t}$ expressed by Conditional Value at Risk (CoVaR) and reflects the loss of the system's market capitalization. As robustness assessment we also employ the Marginal Expected Shortfall (MES) that reflects bank i's from country $\mathrm{j}$ exposure to systemic risk in quarter $\mathrm{t}$ (expressed in \% loss of the banks' market capitalization).

The main regressors of interest are represented by general macroprudential policies (Capital requirements, Sector capital buffers, Reserve requirements on foreign currency $(\mathrm{FX})$ denominated accounts and Reserve requirements on local currency denominated accounts) and housing macroprudential policies (Countercyclical capital requirements, Loan loss provisioning, Debt-Service-toIncome (DSTI) lending criteria and Risk weights on housing loans) adopted by country $\mathrm{j}$ in period $\mathrm{t}-1$. The specification includes bank characteristics (Size, Capitalization, Credit risk, Liquidity risk and Funding), market and macro controls (Lerner index, Foreign bank assets and Inflation), and, bank fixed effects. Variables are winsorized within the $1 \%$ and $99 \%$ percentiles and lagged one period. Their definition is given in Table 1 and a detailed description is provided in Section 4.

\section{Table 1 Description of Variables}

\begin{tabular}{|c|c|c|c|}
\hline Variables & Definition & Level & Source \\
\hline \multicolumn{4}{|c|}{ Dependent variables } \\
\hline CoVaR & $\begin{array}{l}\text { Conditional Value at Risk of Adrian and Brunnnermeier } \\
\text { (2016). The systemic risk measure is expressed in units } \\
\text { of percentage loss of the system's market value of equity } \\
\text { within a quarter. It is determined using Quantile } \\
\text { Regression method, as the average return on the } \\
\text { system's market equity on the days the bank i's market } \\
\text { equity experienced its } 1 \% \text { worst outcomes. System is } \\
\text { defined by the Market capitalization of the sample. } \\
\text { Higher values are associated with increased contribution } \\
\text { of banks to systemic risk. }\end{array}$ & $\begin{array}{l}\text { bank- } \\
\text { quarter }\end{array}$ & $\begin{array}{l}\text { Own estimations based } \\
\text { on market data from } \\
\text { Worldscope, } \\
\text { Datastream and FITCH } \\
\text { and balance sheet data } \\
\text { from Worldscope. }\end{array}$ \\
\hline MES & $\begin{array}{l}\text { Marginal expected shortfall of Acharya et al. (2017). The } \\
\text { systemic risk measure is expressed in units of } \\
\text { percentage loss of the banks' market value of equity } \\
\text { within a quarter. The measure is determined using DCC } \\
\text { - GJR GARCH method as the average return on bank's } \\
\text { market equity on the days the total market capitalization } \\
\text { of the sample experienced its } 1 \% \text { worst outcomes. } \\
\text { System is defined by the Market capitalization of the } \\
\text { sample. Higher values are associated with increased } \\
\text { exposure of banks to systemic risk. }\end{array}$ & $\begin{array}{l}\text { bank- } \\
\text { quarter }\end{array}$ & $\begin{array}{l}\text { Own estimations based } \\
\text { on market data from } \\
\text { Worldscope, } \\
\text { Datastream and FITCH } \\
\text { and balance sheet data } \\
\text { from Worldscope. }\end{array}$ \\
\hline VaR & $\begin{array}{l}\text { Value at Risk measure of Dowd (1998), Jorion (1997) } \\
\text { and Saunders (1999). The individual risk measure is } \\
\text { expressed in units of percentage loss of the banks' } \\
\text { market equity within a quarter. Higher values are } \\
\text { associated with increased banks' individual risk. }\end{array}$ & $\begin{array}{l}\text { bank- } \\
\text { quarter }\end{array}$ & $\begin{array}{l}\text { Own estimations based } \\
\text { on market data from } \\
\text { Worldscope, } \\
\text { Datastream and FITCH } \\
\text { and balance sheet data } \\
\text { from Worldscope. }\end{array}$ \\
\hline DTD & $\begin{array}{l}\text { Individual risk measure of Duan and Wang (2016). The } \\
\text { individual risk measure is expressed in standard } \\
\text { deviations of banks' distance to default within a quarter. } \\
\text { Higher values are associated with reduced banks' } \\
\text { individual risk. }\end{array}$ & $\begin{array}{l}\text { bank- } \\
\text { quarter }\end{array}$ & $\begin{array}{c}\text { Credit Rating Initiative } \\
\text { of Risk Management } \\
\text { Institute }\end{array}$ \\
\hline \multicolumn{4}{|c|}{ Macroprudential policy measures } \\
\hline $\begin{array}{l}\text { Capital } \\
\text { requirements }\end{array}$ & $\begin{array}{l}\text { Change in capital requirements. Implementation of Basel } \\
\text { capital agreements. Positive values are associated with } \\
\text { the number of tightening events, negative values with } \\
\text { the number of loosening events, } 0 \text { reflects no action. }\end{array}$ & $\begin{array}{l}\text { country- } \\
\text { quarter }\end{array}$ & Cerutti et al. (2016) \\
\hline
\end{tabular}




\begin{tabular}{|c|c|c|c|}
\hline $\begin{array}{l}\text { Sector capital } \\
\text { buffers }\end{array}$ & $\begin{array}{l}\text { Sum of changes in sector-specific capital buffers across } \\
\text { the residential, consumer, and other sectors. Requires } \\
\text { banks to finance a larger fraction of these exposures } \\
\text { with capital. Positive values are associated with the } \\
\text { number of tightening events, negative values with the } \\
\text { number of loosening events, } 0 \text { reflects no action. }\end{array}$ & $\begin{array}{l}\text { country- } \\
\text { quarter }\end{array}$ & Cerutti et al. (2016) \\
\hline $\begin{array}{l}\text { Reserve } \\
\text { requirements } \\
\text { FX }\end{array}$ & $\begin{array}{c}\text { Change in reserve requirements on foreign currency- } \\
\text { denominated accounts. Positive values are associated } \\
\text { with the number of tightening events, negative values } \\
\text { with the number of loosening events, } 0 \text { reflects no } \\
\text { action. }\end{array}$ & $\begin{array}{l}\text { country- } \\
\text { quarter }\end{array}$ & Cerutti et al. (2016) \\
\hline $\begin{array}{l}\text { Reserve } \\
\text { requirements } \\
\text { local }\end{array}$ & $\begin{array}{l}\text { Change in reserve requirements on local currency- } \\
\text { denominated accounts. Positive values are associated } \\
\text { with the number of tightening events, negative values } \\
\text { with the number of loosening events, } 0 \text { reflects no } \\
\text { action. }\end{array}$ & $\begin{array}{l}\text { country- } \\
\text { quarter }\end{array}$ & Cerutti et al. (2016) \\
\hline $\begin{array}{l}\text { Countercyclical } \\
\text { capital } \\
\text { requirements }\end{array}$ & $\begin{array}{c}\text { Housing - countercyclical capital requirements. Positive } \\
\text { values are associated with the number of tightening } \\
\text { events, negative values with the number of loosening } \\
\text { events, } 0 \text { reflects no action. }\end{array}$ & $\begin{array}{l}\text { country- } \\
\text { quarter }\end{array}$ & $\begin{array}{l}\text { Akinci and Olmstead- } \\
\text { Rumsey (2018) }\end{array}$ \\
\hline $\begin{array}{l}\text { Loan loss } \\
\text { provisioning }\end{array}$ & $\begin{array}{l}\text { Housing - loan loss provisioning. Positive values are } \\
\text { associated with the number of tightening events, } \\
\text { negative values with the number of loosening events, } 0 \\
\text { reflects no action. }\end{array}$ & $\begin{array}{l}\text { country- } \\
\text { quarter }\end{array}$ & $\begin{array}{l}\text { Akinci and Olmstead- } \\
\text { Rumsey (2018) }\end{array}$ \\
\hline $\begin{array}{l}\text { DSTI lending } \\
\text { criteria }\end{array}$ & $\begin{array}{l}\text { Debt to service income limits lending criteria. Positive } \\
\text { values are associated with the number of tightening } \\
\text { events, negative values with the number of loosening } \\
\text { events, } 0 \text { reflects no action. }\end{array}$ & $\begin{array}{l}\text { country- } \\
\text { quarter }\end{array}$ & $\begin{array}{l}\text { Kuttner and Shim } \\
\qquad(2016)\end{array}$ \\
\hline $\begin{array}{l}\text { Risk weights } \\
\text { on housing } \\
\text { loans }\end{array}$ & $\begin{array}{c}\text { Risk weights applied to housing loans. Positive values } \\
\text { are associated with the number of tightening events, } \\
\text { negative values with the number of loosening events, } 0 \\
\text { reflects no action. }\end{array}$ & $\begin{array}{l}\text { country- } \\
\text { quarter }\end{array}$ & $\begin{array}{l}\text { Kuttner and Shim } \\
\text { (2016) }\end{array}$ \\
\hline \multicolumn{4}{|l|}{ Bank controls } \\
\hline Size & $\log$ (Total assets) & $\begin{array}{l}\text { bank- } \\
\text { quarter }\end{array}$ & Worldscope \\
\hline Capitalization & Common equity/Total assets (\%) & bank- & Worldscope \\
\hline Credit risk & Provisions for loan losses/Gross loans (\%) & $\begin{array}{l}\text { bank- } \\
\text { quarter }\end{array}$ & Worldscope \\
\hline Liquidity risk & $\begin{array}{l}\text { Net loans/Short term debt \& Current portion of long term } \\
\text { debt (\%) }\end{array}$ & $\begin{array}{l}\text { bank- } \\
\text { quarter }\end{array}$ & Worldscope \\
\hline Funding & Deposits/Total assets (\%) & $\begin{array}{l}\text { bank- } \\
\text { quarter }\end{array}$ & Worldscope \\
\hline \multicolumn{4}{|c|}{ Macro controls } \\
\hline Lerner index & $\begin{array}{c}\text { Lerner index, a measure of market power in the banking } \\
\text { market, which compares the output pricing and the } \\
\text { marginal costs. }\end{array}$ & $\begin{array}{l}\text { country- } \\
\text { year }\end{array}$ & World Bank \\
\hline $\begin{array}{l}\text { Foreign bank } \\
\text { assets }\end{array}$ & Foreign bank assets/Total bank assets (\%) & $\begin{array}{l}\text { country- } \\
\text { year }\end{array}$ & World Bank \\
\hline $\begin{array}{l}\text { Supervisory } \\
\text { authority } \\
\text { independence }\end{array}$ & $\begin{array}{l}\text { The degree to which the supervisory authority is } \\
\text { independent from the government and legally protected } \\
\text { from the banking industry. The index ranges between } 0 \\
\text { and } 3 \text {, higher values indicating greater independence. }\end{array}$ & $\begin{array}{l}\text { country- } \\
\text { year }\end{array}$ & Barth et al. (2013) \\
\hline Inflation & Inflation measured by the consumer price index & $\begin{array}{l}\text { country- } \\
\text { year }\end{array}$ & World Bank \\
\hline
\end{tabular}

Notes: This table summarizes the definition of variables used in the empirical analysis, along with their frequency and data sources.

\subsection{The Impact of Macroprudential Measures on Banks' Risk Taking}

The impact of macroprudential policies on banks' individual risk is examined using the following regression specification estimated using the OLS Fixed Effects with country level clustered standard errors: 
Individual Risk $_{i j, t}=\beta_{0}+\boldsymbol{\beta}_{1} \times$ Macroprudential Policies $i j, t-1_{1}+\Phi \times$ Bank $_{\text {controls }}{ }_{i j, t-1}$

$+\Psi \times$ Market \& Macro controls $s_{j, t-1}+\varphi_{i}+\mu_{j}+v_{t}+\varepsilon_{i j, t}$

The dependent variable is represented by bank i's from country j individual risk in quarter $\mathrm{t}$ expressed by the Value at Risk (VaR) measure proposed by Jorion (1997). In a robustness exercise, we employ the Distance to Default (DTD) measure of Duan and Wang (2012). Both measures require data on market equity. VaR reflects the maximum percentage loss of the banks' market equity within a quarter for a given confidence level, higher values corresponding to increased banks' individual risk. DTD measures the deviation of assets value from the default point, higher values being associated with reduced banks' individual risk.

The main regressors of interest that consists of general and real estate macroprudential policies as well as the bank characteristics and market and macro controls are the same as in Eq. (1). Variables are winsorized within the $1 \%$ and $99 \%$ percentiles and lagged one period. Their definition is given in Table 1 and a detailed description is provided in Section 4.

\subsection{Further Analysis}

In the second part of the analysis, we investigate the impact of macroprudential measures adopted by central authorities across different banks and banking systems. We use the difference-in-difference methodology in order to assess if the impact of the adopted macroprudential measures was amplified or diminished by different characteristics of banks or banking market conditions.

First, we considered the size of banks, as it is often associated in the literature as a key determinant for the bank's systemic importance (Tarashev et al., 2010; Vallascas and Keasey, 2012; Laeven et al., 2016). In addition, size might create incentives for financial institutions to take on more risk as a result of the "too-big-tofail" belief (Brown and Dinc, 2009).

Next, we account for the impact of the share of foreign assets in total banks assets at the country level. We choose the banking system foreign assets to highlight the international activity of banks and the risks they assume in an interconnected banking network. Interconnection poses greater threats to the stability of banking systems starting to serve as a mechanism for the propagation of shocks (Acemoglu et al., 2015).

Other banking market characteristics considered are the level of competition proxied by the Lerner index, and, the degree to which the supervisory authority is independent from the government and legally protected from the banking industry. Banking competition offers details regarding the banks disposal to reflect the regulatory changes imposed by central authorities. The degree of supervisory authority's independence it is important because governments cannot influence the adopted policies to their advantage.

In order to assess the impact of macroprudential measures across different types of banks and banking markets the following empirical regression form is estimated using the OLS Fixed Effects with country level clustered standard errors: 


$$
\begin{gathered}
\text { Risk }_{i j, t}=\beta_{0}+\boldsymbol{\beta}_{1} \times \text { Macroprudential Policies }_{i j, t-1}+\boldsymbol{\beta}_{2} \times \text { Macroprudential } \\
\text { Policies }_{i j, t-1} \times Z_{(i) j, t-1}+\boldsymbol{\beta}_{3} \times Z_{(i) j, t-1}+\Phi \times \text { Bank controls }_{i j, t-1}+\Psi \times \text { Market \& Macro } \\
\text { controls }_{j, t-1}+\varphi_{i}+\mu_{j}+v_{t}+\varepsilon_{i j, t}
\end{gathered}
$$

Risk $_{\mathrm{ij}, \mathrm{t}}$ takes alternatively the form of systemic risk (CoVaR and MES) and

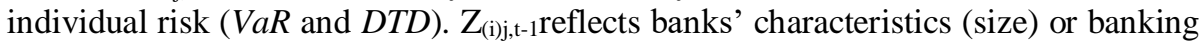
systems conditions (share of foreign assets among total banking assets, Lerner index, and the independence of supervisory authority). The main regressors of interest that consists of general and real estate macroprudential policies as well as the bank characteristics and market and macro controls are the same as in Eq. (1). Variables are winsorized within the $1 \%$ and $99 \%$ percentiles and lagged one period. Their definition is given in Table 1 and a detailed description is provided in Section 4.

\section{Data}

\subsection{Sample}

Our sample consists of 95 publicly listed banks from 21 countries. The majority of these banks are located in Europe, but we also added banks from Canada and USA (Appendix B summarizes the distribution of banks among countries). We extended our sample with banks from USA and Canada, as they implemented important measures to sustain the resilience of the banking system (i.e., TARP program $)^{2}$ and to limit the boom of real estate credit (i.e., tax credit for homebuyers). In addition, the USA banking system consists of the majority of the global systemically important banks. The sample includes 26 USA financial institutions, 63 banks from Europe (among which 56 are from European Union, and 37 banks from Eurozone), and 6 Canadian banks.

The analyzed financial institutions have a total assets value of approximately 38 trillion dollars at the end of 2014 (Appendix 2), ranging from $12 \$$ billion to $\$ 2.6$ trillion. From these banks, 12 are included in the G-SIBs list published in November 2016 by the Financial Stability Board. The European Banking Authority considers banks with an exposure over 200 billion EUR as systemically important institutions and recommends they be subjected to the same disclosures as the G-SIBs (16 countries from our sample are included in the EBA list as of 2016). In addition, we also include other financial institutions that can generate negative contagion spillover across the system and are systemically important from a national perspective.

\subsection{Dependent Variables}

To assess the effectiveness of macroprudential policies implemented by central banks from our sample countries, we analyzed their impact on banks' contribution to systemic risk and risk-taking.

The global financial crisis showed that the failure of large complex crossborder financial institutions can have severe effects on the financial system and the economy, both domestically and globally. Considering the major implications of large and highly interconnected financial institutions, authorities and regulators were forced to implement new measures to increase their resilience to shocks and limit

2 TARP (Troubled Asset Relief Program) provided capital to 707 banks that totaled $\$ 245.1$ billion. 
their exposures. Once contagion risk is spreading, authorities have limited alternatives to stop it, undermining financial stability. One of the solutions to restore the confidence is to bailout the banks in need, but the central resources are limited. Therefore, the primary question is which financial institutions authorities should favor. At this point, it is important to identify the systemic importance of banks.

Several researchers (see e.g. Adrian and Shin, 2010) have conducted theoretical research on the identification of systemically important financial institutions. Considering this literature as a starting point, our systemic risk indicators are measured in a time-varying manner through CoVaR (Conditional Value at Risk) of Adrian and Brunnermeier (2017) and MES (Marginal Expected Shortfall) of Acharya et al. (2017). Both measures are based on weekly market capitalization data extracted from Datastream. While CoVaR captures the negative spillover effects of a reduction in a bank's market capitalization to the system (i.e., contribution to systemic risk), MES estimates the contagion developments when the system as a whole is undercapitalized to a particular bank (i.e., exposure to systemic risk). System is defined by the total market capitalization of the banks from our sample. CoVaR and MES are calculated separately for each bank using weekly returns of market capitalization for the period 2005-2014 to account for the build up phase in the pre-crisis period and the propagation phase during the crisis. Returns on bank i's market capitalization in week $t$ are computed as follows:

$$
\mathrm{R}_{\text {Market capitalization }(\mathrm{t})}^{\mathrm{i}}=\frac{\text { Market capitalization }_{\mathrm{t}}^{\mathrm{i}}}{\text { Market capitalization }_{\mathrm{t}-1}^{\mathrm{i}}}-1
$$

Returns on the system's market capitalization in week $\mathrm{t}$ are determined using the aggregated values of our all banks' market capitalization:

$$
\mathrm{R}_{\text {Market Assets ( } \mathrm{t})}^{\text {sys }}=\sum_{\mathrm{i}} \frac{\text { Market capitalization }_{\mathrm{t}}^{\mathrm{i}}}{\sum_{\mathrm{i}} \operatorname{Market~capitalization~}_{\mathrm{t}}^{\mathrm{i}}} \times \mathrm{R}_{\text {Market capitalization }(\mathrm{t})}^{\mathrm{i}}
$$

To determine CoVaR we use the quantile regression method following the procedure of Adrian and Brunnermeier (2017), while for MES we use a DCC-GJR GARCH model as in Acharya et al. (2017). The weekly values are then summed within a quarter for each bank. The descriptive statistics presented in Table 2 show that during 2008-2014, the quarterly average contribution to systemic risk of all banks from our sample translates to about 5\% loss of the system's market equity. On the other hand, the exposure to systemic risk of the banks involves a quarterly loss of the banks' market equity of about $8 \%$. A detailed situation of each bank's average contribution and exposure to systemic risk is provided in Appendix B. 


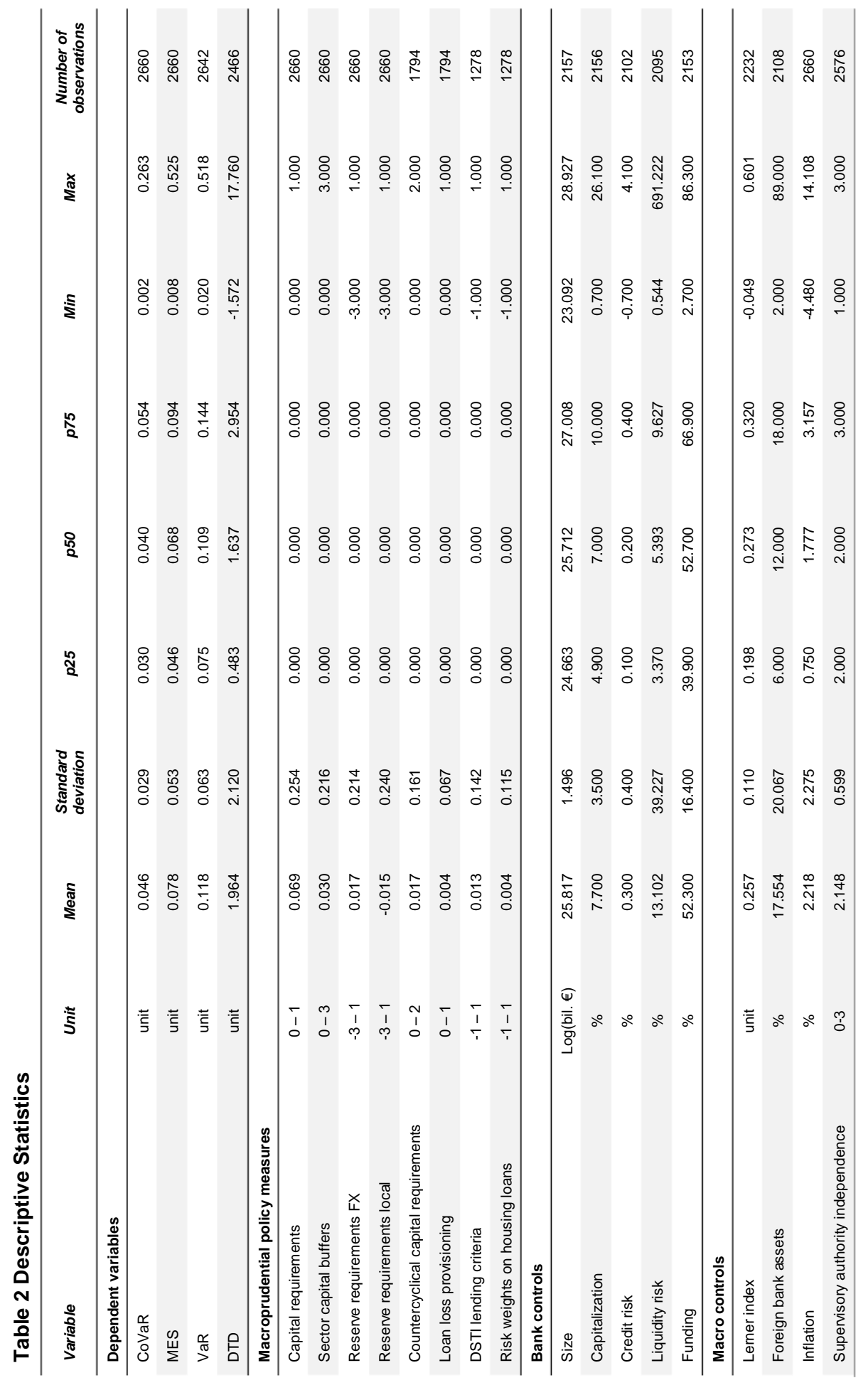


The bank risk-taking is computed using the Value at Risk (VaR) and Distanceto-Default (DTD) measures. VaR is estimated separately for each bank using weekly returns of market equity for the period 2005-2014. The risk we assess is the reduction of each bank's market capitalization. For quantifying this idiosyncratic risk we determine the VaR indicator that expresses the maximum possible loss (as a percent of the total market capitalization) that a bank could register for a given confidence level $\alpha$ (usually 99\%), over a specific period of time. ${ }^{3}$ The $q^{\text {th }}$ quantile (corresponding to the significance level $\mathrm{q}=1-\alpha$ ) of the following loss function is estimated using the quantile regression method:

$$
q=\operatorname{Prob}\left(R_{\text {Market capitalization, } t}^{i} \leq \operatorname{VaR}_{q, t}^{i}\right)
$$

The weekly estimates obtained are then summed within a quarter for each bank. The descriptive statistics reported in Table 2 show that during 2008-2014 period our sample is characterized by a quarterly average of individual risk of about $12 \%$ loss of banks' market capitalization, with important differences among banks. The safest bank presents a quarterly average of $4 \%$ loss of its market capitalization, while the riskiest one has a quarterly average individual risk of $26 \%$ loss of its market equity (as depicted in Appendix B).

Distance-to-Default (DTD) was retrieved from Duan and Wang (2012). The measure is constructed as a function of different input variables that are firm-specific or common to all firms within an economy. The selected common variables that have the greatest predictive power for banks' default are stock index returns and interest rates. The firm-specific variables consist of volatility-adjusted leverage, liquidity, profitability, relative size, market misevaluation/future growth opportunities and idiosyncratic volatility. For banks, it is necessary to include also liabilities with a haircut at the default point, as they have high leverage levels. The method that captures these is the transformed-data $M L E$ proposed by Duan et al. (2012). Descriptive statistics (Table 2) shows an average DTD indicator of 1.96 standard deviations of banks' distance to default within a quarter. Higher values are associated with reduced banks' individual risk.

The risk measures we use as dependent variables combine accounting data (size, leverage) with market data (stock prices). In comparison with other risk measures, like for example the widely used Z-score that rely on accounting data, DTD can provide forward-looking information reflected in banks' market capitalization movements. However, the 2008 financial crisis showed the need to adjust both accounting and market-based risk measures with the interlinkages among financial institutions, thus approaches like CoVaR or MES can better reflect contagion spillovers across the banking system as well as the importance of banks within a system.

\footnotetext{
${ }^{3}$ This theoretical developments of the Value at Risk indicator can be found in Jorion (1997).
} 


\subsection{Independent Variables}

\subsubsection{Macroprudential Policies}

In order to assess the effectiveness of macroprudential policies we use several databases, compiled by Akinci and Olmstead-Rumsey (2018), Kuttner and Shim (2016), Cerutti et al. (2017b) and Vandenbussche et al. (2015). These databases describe the macroprudential policies adopted during the period 2000-2014 by various countries (see Appendix 1 for a detailed description of each database).

Kuttner and Shim (2016) ${ }^{4}$, Akinci and Olmstead-Rumsey (2018) and Cerutti et al. (2017b) used an index that captures the policy changes within a quarter, with entries of 1 if the prudential tool was tightened, -1 if the instrument was loosen and 0 when no change occurs. If multiple actions in the same direction (tightening or loosening) occur within a given quarter, the entries could take on the values of 2 and -2 or 3 and -3 . In addition, a tightening and a loosening measure adopted within the same quarter would cancel each other.

In the following analysis, we will focus on the previously mentioned databases as they used the same mechanism in defining the policy changes ${ }^{5}$. In addition, the first three databases have various measures from several categories: solvency, liquidity, housing, non-housing that will allow us to run a series of comparative analyses. Other arguments for choosing these three databases are that they include the same countries and the period considered is larger than that assessed by Bakker and Klingen (2012) and Vandenbussche et al. (2015).

From the databases mentioned above, we use data regarding non-housing measures (general macroprudential policies): capital requirements, sector capital buffers, reserve requirements on foreign-currency denominated accounts and on local currency-denominated accounts, and real estate specific measures (housing macroprudential policies): countercyclical capital requirements, loan loss provisioning, DSTI lending criteria and risk weights on housing loans. Our analysis focuses on non-housing macroprudential measures aimed to increase the financial system's resilience and on housing related policy tools designed to restore the stability of real estate sector, as advanced economies used primarily this type of policies (Akinci and Olmstead-Rumsey, 2018). From borrower-based macroprudential policies we focused on DSTI lending criteria, as this measure is not related to the real estate market, property prices reaching unsustainable levels during the real estate bubble. As confirmed by Gross and Garcia (2016), DTI ratios are more effective than LTV caps reducing the household risk (probability of default and lossgiven-default) while implying less pronounced macro feedback effects. Descriptive statistics are highlighted in Table 2, while the definitions of macroprudential measures and sources are provided in Table 1.

\footnotetext{
${ }^{4}$ The database of Kuttner and Shim (2016) contains monthly values for each policy change. In order to facilitate the comparison between databases we transformed the monthly values to quarterly values, by summing the values of each quarter months.

${ }^{5}$ Vandenbussche et al. (2015) studied the macroprudential measures adopted by countries from Central and Eastern Europe in period 2000Q1-2010Q4, focusing on the effective value of individual measures that could be subject of interpretation when we transform the values to reflect policy changes.
} 
We consider the impact of the above macroprudential measures as they were the most frequently implemented during 2008-2014 period in countries from our sample. Although, the usage of macroprudential policies increased after 2000s, the regulatory authorities started to share a greater recognition for the relevance of macroprudential policies after the financial crisis. Therefore, we examine the impact of macroprudential policy during the crisis phase $\left(2008 \mathrm{Q}_{3}-2011 \mathrm{Q}_{4}\right)$ and post-crisis $\left(2012 Q_{1}-2014 Q_{4}\right)$ to capture the deteriorating financial conditions and their consequences.

We expect that tighter capital regulation, including capital requirements, sector capital buffers and countercyclical capital requirements, reduce systemic risk as they increase the cost of funding or constrain the credit growth. This situation may be managed through more stringent credit conditions supported by borrowers that may decrease the credit demand. In the same time it can improve the financial situation of banks as a result of borrowing loans to clients that meet the tighten requirements, thus lowering the risks assumed. The same mechanism can be applied also for risk-weights on housing loans when the target is the real estate sector.

Higher reserve requirements may increase the cost of funding less liquid assets such as residential mortgages and may force banks to reduce their supply and, therefore the level of risk-taking. If we refer to provisioning requirements, these may force banks to save a larger portion of their earnings to cover potential losses, reducing their profits. Consequently, a bank with lower profitability increases the cost of funding and tightens credit conditions with the same effect as capital measures. Increasing the DSTI ratio makes more difficult for households with limited own funds and low income to qualify for a credit, thereby reducing the risk assumed by banks, and implicitly their contribution to systemic risk. Table 3 summarizes the number of tightening and loosening events of the macroprudential measures by year (Panel A) and by country (Panel B). Overall, data highlight the necessity to provide urgent liquidities to financial market and to increase banks' resilience to further shocks. For example, sector capital buffers were increased on average three times in one quarter, while reserve requirements on foreign-currency denominated accounts and on local currency-denominated accounts were loosen three time in one quarter. 


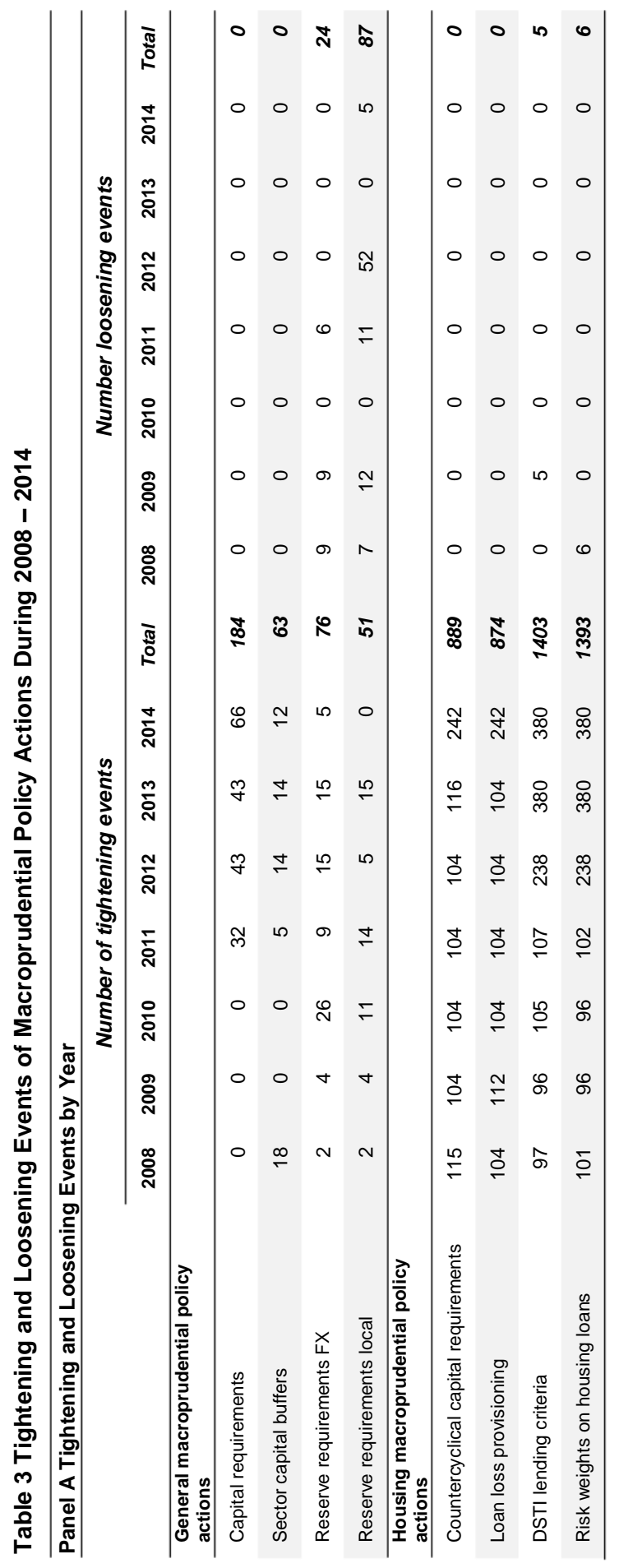

Finance a úvěr-Czech Journal of Economics and Finance, 68, 2018, no. 3 


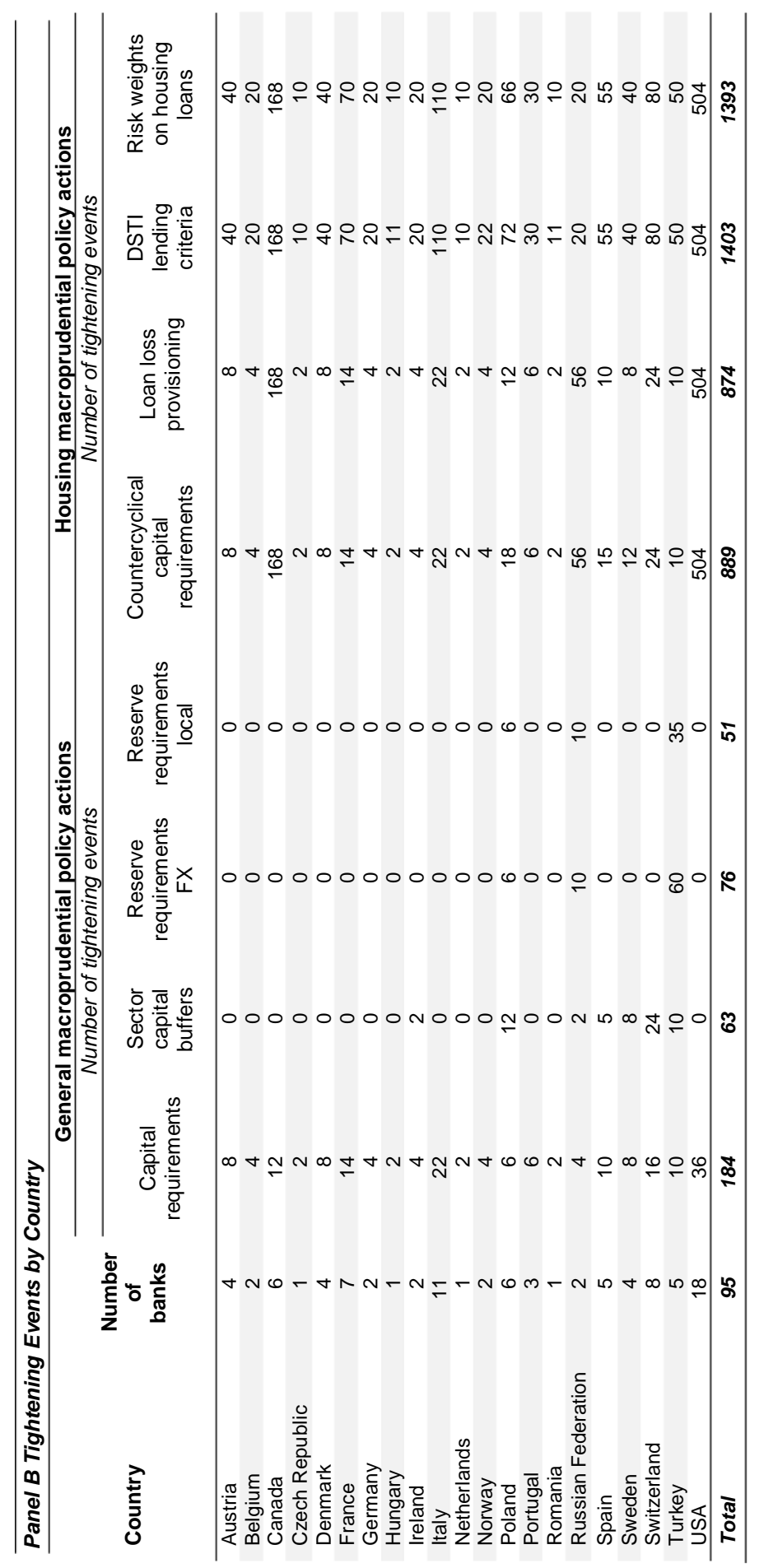


If we refer to the number of tightening and loosening actions by year, for both categories of measures (housing and non-housing) the number of tightening events increased during 2011 - 2014, compared with previous period (Table 3, Appendix A). This can be explained by the fact that, countries from Europe adopted the majority of macroprudential measures during the sovereign debt crisis, as the systemic risk of European banks reached its height in late 2011. During this crisis, the largest increase in contribution to systemic risk came from the Italian and Spanish banks (Black et al., 2016)

Central authorities from all countries reacted to financial difficulties by limiting (tightening) or encouraging the activity (loosening) in order to improve banking stability. In Europe, during the analyzed period, Italy implemented 286 tightening actions, followed by Switzerland (248) and Turkey (235), while Czech Republic implemented only 26 tightening actions. The implemented measures restricted the conditions for borrowers in several countries, including France, Italy, Spain, Switzerland, and Poland (Table 3, Appendix B).

\subsubsection{Bank-Control Variables}

Empirical specifications control for banks' characteristics, in order to capture the strategies they follow for risk management. Therefore, we account in our regression analysis for banks' size (logarithm of Total Assets), capitalization (Common Equity to Total Assets), credit risk (Provisions for Loan Losses to Gross Loans), liquidity risk (Net Loans to Short Term Debt and Current portion of Long Term debt) and the funding structure (Deposits to Total Assets). Variables are extracted from Worldscope and their definition is given in Table 1.

Literature suggests that size and leverage are the key determinants of banks' contribution to systemic risk. The banks' dimension is recognized in various papers as an important determinant of systemic importance of an institution (Tarashev, et al., 2010; Vallascas and Keasey, 2012; Mayordomo et al., 2014; Laeven et al., 2016). Vallascas and Keasey (2012) provide evidence from an extensive sample of European listed banks regarding the importance of banks' size in their exposure to systemic risk. This might be explained by the fact that relatively large banks are more likely to benefit from regulatory forbearance and this might create incentives to invest in risky activities (Brown and Dinc, 2009). On the other side, Dermine and Schoenmaker (2010) sustain that limiting the banks' size will generate a lack of credit risk diversification, that is needed to reduce the cost of financial distress.

Previous studies show that systemic risk is associated with high level of leverage. Adrian and Shin (2010) and Danielsson et al. (2013) highlight the importance of financial leverage in influencing systemic risk. Vallascas and Keasey (2012) consider that in order to increase banks' resilience to systemic events, central authorities should apply restrictions on banks' leverage and constrain the liquidity requirements. On the other hand, Wei $\beta$ et al. (2014) sustain that neither bank size nor leverage are persistent determinants of systemic risk across financial crises, however, global systemic risk is generated by characteristics of regulatory regime. Other important determinants of systemic risk during the recent financial crisis have been credit and liquidity risk (Lopez-Espinosa et al., 2012). Finally, the ratio of deposits to 
total assets has been used also by Anginer et al. (2014b) in order to explain financial stability, measured by Z-score.

Descriptive statistics for these variables are presented in Table 2. We can observe that on average during 2008-2014 banks from our sample had a capitalization of $7 \%$ (ranging from $4.9 \%$ to $26.1 \%$ ) and a share of deposits in total assets of about $52 \%$. There are important differences among banks regarding credit risk and liquidity risk.

\subsubsection{Macro and Sector-Specific Variables}

To estimate the impact of macroprudential measures on systemic and individual risk we control for sector-specific and macroeconomic characteristics. Therefore, we add an indicator that accounts for banking competition (Lerner index), banking foreign activity (foreign bank assets among total bank assets) and, finally, as macro variable we employ the inflation rate. Variables are extracted from World Bank and their definitions are detailed in Table 1.

The level of banking competition influences the level of bank risk-taking. Anginer et al. (2014a) provided empirical evidence that greater competition encourages banks to take on more diversified risks, making the banking system less fragile to shocks. On the other hand, Beck et al. (2013) and Jimenez et al. (2013) found that an increase in competition, measured by the Lerner index, is associated with larger increase in banks' fragility. Foreign currency loans contribute to systemic risk by creating a significant exchange-rate-induced credit risk. This situation occurs mainly in European countries, were loans denominated in EUR or CHF predominate. Yesin (2013) found that systemic risk is substantial in the non-euro area and relatively low in the euro area. Finally, in order to account for the macroeconomic environment we used the inflation rate. Although the financial situation started to deteriorate beginning with 2007 (significant losses from subprime mortgages in US), the difficulties have been transmitted to the economy lately. Inflation rate for the sample countries registered the highest values during 2008 year, followed by a substantial reduction during 2009. This variable was also used by Wei $\beta$ et al. (2014) as macro control variable in order to explain systemic risk.

The descriptive statistics presented in Table 2 show that the banking systems from our sample are characterized by an average Lerner index of 0.25 . Foreign loans represent on average $17.55 \%$ of total assets, with important differences among banks (standard deviation 20.07\%). There are banking systems with the majority of banks' activity focused on foreign denominated loans (the ratio of foreign assets to total assets is $89 \%$ ), while there are banking systems which banks manifest risk aversion and prefer to focus on domestic denominated loans.

\section{Results}

This section presents estimates of the general and housing macroprudential policies effects on banks' systemic importance and risk-taking level. The impact was assessed in a panel framework using the OLS methodology. Also, we explore the asymmetric responses of banks' risk to macroprudential measures considering their size and a number of banking sector characteristics like foreign assets holdings, competition and independence of the supervisory authority. 


\subsection{The Impact of Macroprudential Policies on Systemic Risk}

Table 4 presents the results of the macroprudential measures impact on banks' contribution to systemic risk expressed by CoVaR. The main regressors of interest include country specific macroprudential measures implemented by governments and take values from -3 to 3 . Positive values are associated with the number of tightening events within a quarter, while negative values are linked to the number of loosening events (0 reflects no action). Column (1) depicts the benchmark model that includes all types of macroprudential policies, column (2) covers the general prudential measures, and, column (3) focuses on housing specific measures. In columns (4)-(11) we include alternatively the macroprudential tools. All models include bank controls, sector specific and macro characteristics, and, bank fixed effects. Positive coefficients correspond to an enhanced contribution to systemic risk (harmful effect), while negative coefficients are associated with a reduction in banks' systemic importance (beneficial effect).

The baseline model (column 1) provides evidence for highly significant effectiveness of sector capital buffers, countercyclical capital requirements and DSTI lending criteria in reducing banks' systemic importance. These results are in line with the literature regarding the impact of various macroprudential policies on systemic risk. The target of capital buffers is to increase banks' capacity to absorb losses generated by the interconnection among banks, while countercyclical capital requirements' aim is to mitigate procyclicality (Bui et al., 2017). Lim et al. (2011) concluded that countercyclical capital requirements are effective in reducing systemic risk, but the magnitude depends on the source of shock. Claessens et al. (2013) and Hallissey et al. (2014) argue that borrower-based measures (DSTI) are effective in reducing asset growth, curbing the associated risk.

We report separately the results associated with non-housing measures (column 2) as the number of banks jumps from 49 to 75 and the number of observations increases accordingly. For this specification the capital requirements imposed by Basel agreements become statistically significant, as the aim of Basel III requirements is to improve bank' capacity to absorb shocks, develop prudent risk management practices and raise the resilience of individual banks in times of distress. The importance of higher regulatory capital levels in reducing systemic risk is highlighted in various papers (Bluhm and Krahnen, 2014; Laeven et al., 2016). These results are confirmed by models (4)-(7), which accounts for the separate influence of the general macroprudential policies.

Although insignificant, reserve requirements for deposits denominated in local and foreign currency have a negative impact on the dependent variable being associated a reduction in the banks' contribution to systemic risk (columns 6 and 7). A similar conclusion has been obtained by Bruno et al. (2016) and Kuttner and Shim (2016).

Turning to housing sector related macroprudential measures (model 3) the only tools that maintain their significance are countercyclical capital requirements and DSTI lending criteria. The significant impact of these measures is confirmed also in models (8) and (10).

When the impact of loan loss provisioning mechanism is analyzed separately from the other prudential variables, results show an increase in banks' systemic 
importance (slightly significant). For the Hong Kong banking system, Wong et al. (2011) found that the loan-loss provisioning is a main determinant of systemic risk and the countercyclical tools for loan-loss reserves might be effective in reducing the risk in the banking system. On the other side, higher loan loss provisions can be a signal of higher default risk (Floreani et al., 2015) and, therefore, of greater contagion spillovers across the system.

Regarding the control variables, our paper is in line with the general acceptance that better-capitalized banks contribute less to systemic risk (Tarashev, et al., 2010; Bluhm and Krahnen, 2014). ${ }^{6}$ For the coefficient corresponding to size our findings are similar to Wei $\beta$ et al. (2014) who empirically show that banks' size is not a persistent determinant of systemic risk across financial crises. Banking market competition and the share of foreign assets among total banking assets limit the banks' systemic importance due to risk diversification, while the level of inflation from one country increases the contribution of banks to systemic risk.

We also examined the impact of macroprudential measures on systemic risk using $M E S$ as dependent variable. Results depicted in Appendix $\mathrm{C}$ show that a significant reduction in banks' exposure to systemic risk is associated with the tightening of capital requirements, sector capital buffers, countercyclical capital requirements, loan loss provisioning and DSTI lending criteria, confirming thus the previous empirical output.

\footnotetext{
${ }^{6}$ Large banks actively build-up capital that exceeds the regulatory minimum requirements (Berger et al., 2008). While better-capitalized banks are associated with a lower contribution to systemic risk, they might engage in risky operations (Perotti et al., 2011). To control for this behavior, we replace the capitalization ratio with a capital in excess ratio in alternative specifications. Capital in excess for a given bank is computed as the difference between actual and minimal capital requirement (including bank specific pillar 2 requirements). Unreported results highlight that measures like sector capital buffers, countercyclical capital requirements and DSTI lending criteria could significantly reduce systemic risk when controlling for excess capital available to banks, confirming thus our main findings.
} 


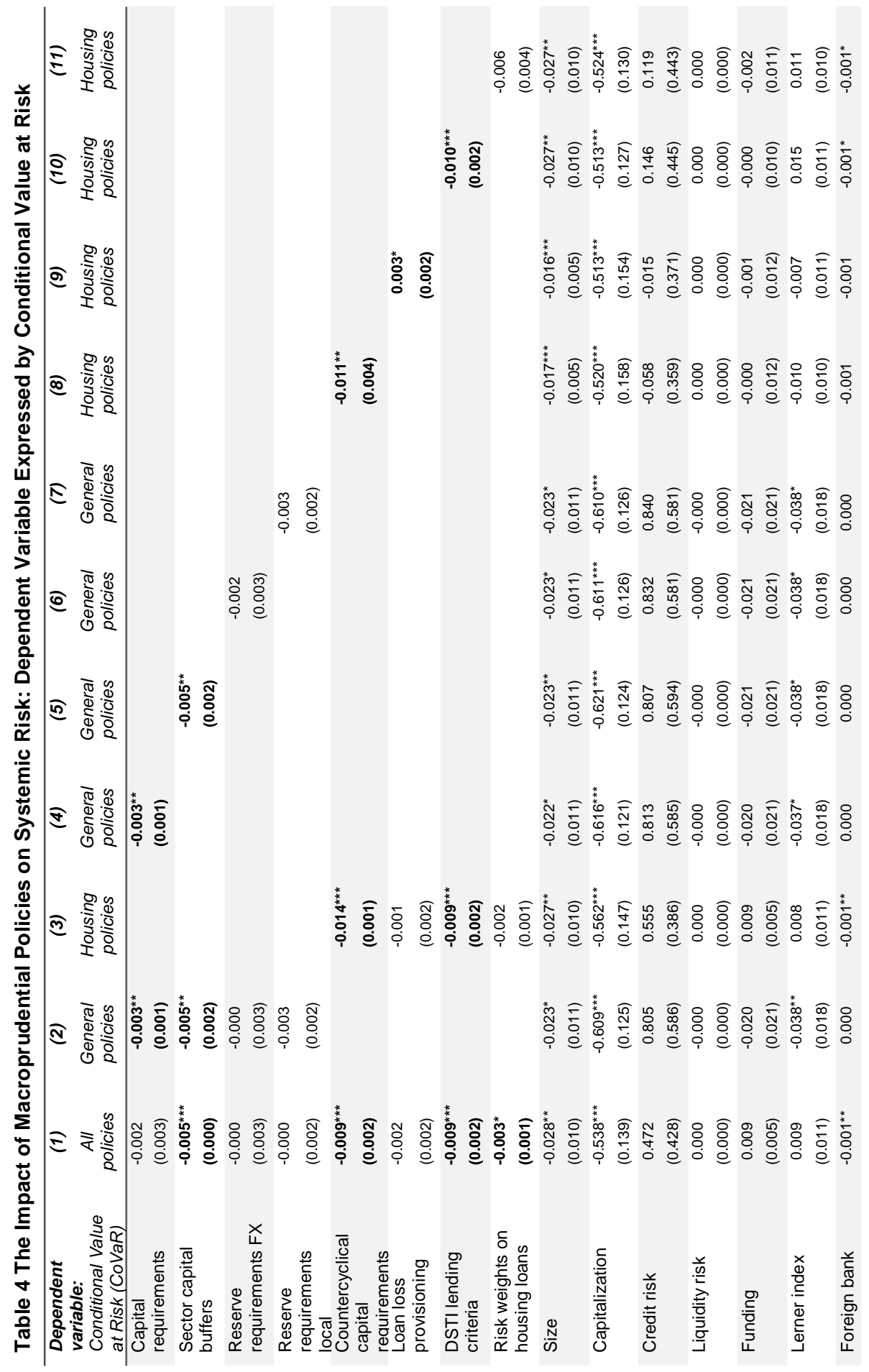




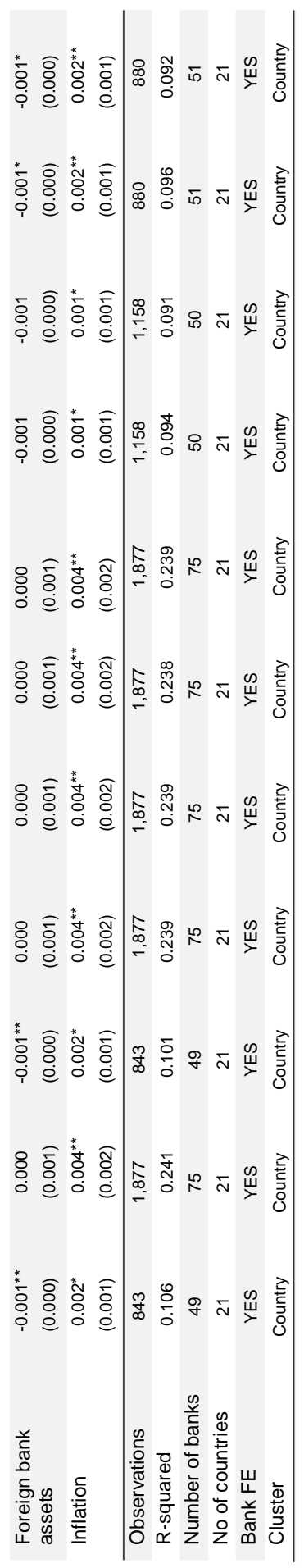




\subsection{The Impact of Macroprudential Policies on Individual Risk}

Results regarding the impact of macroprudential policies on individual risk captured by Value at Risk indicator are presented in Table 5. Model (1) includes the complete set of macroprudential policies and accounts for bank controls, sector specific and macro characteristics, and, bank fixed effects. Column (2) summarizes the estimated coefficients for the general macroprudential policies, while column (3) provides the empirical estimates for the prudential measures related to the real estate sector. For the remaining models (4) to (11) each measure is included one at a time. A positive coefficient corresponds to an enhanced individual risk-taking (harmful effect), while a negative coefficient is associated with a reduction in banks' level of risk-taking (beneficial effect).

Estimation results regarding the baseline model (column 1) highlight that the most effective measures in reducing significantly the individual banking risk are sector specific capital buffers, as well as housing sector related tools like countercyclical capital requirements, DSTI lending criteria and risk-weights on housing loans. These results strengthen the necessity to hold higher levels of capital as safety net (Gauthies et al., 2012; Bluhm and Krahnen, 2014) and to counteract the risks generated by the housing sector because of excessive lending. Overall, results highlight that macroprudential measures targeting the housing sector are more effective than those targeting the entire banking activity where only one measure is statistically significant. Akinci and Olmstead-Rumsey (2018) also pointed out that measures targeting the housing sector were more effective than those targeting the entire banking activity considering that housing credit growth was much larger, on average, than total credit growth during the 2008 financial crisis.

The effectiveness of higher levels of capital in reducing individual banking risk is confirmed by model (2) that focuses on macroprudential measures aimed to sustain the entire banking activity and, also, in models (4), (5) and (8) that analyze the capital measures individually. The positive effects of capital requirements (corresponding to Basel capital agreements) are in line with the literature that sustain the need of higher capital requirements in reducing bank risk-taking, such as Behr et al. (2010) and Thakor (2014), but in this case only in markets with a low degree of concentration. Beltratti and Stulz (2012) found that large banks with more Tier 1 capital, more deposits, less exposure to US real estate and less funding fragility performed better during crisis.

Reserve requirements for liabilities denominated in domestic currency reduce banks' risk (models 1, 2 and 7), while reserve requirements for foreign currency denominated liabilities increase the risk incentives of banks (models 1,2 and 6), but the associated coefficients are not statistically significant. As an explanation for these findings might be the fact that reserve requirements were mainly used by emerging countries (Bustamante and Hamann, 2015) that have limited observations in our sample. In line with our results, Bruno et al. (2016), Kuttner and Shim (2016) and Akinci and Olmstead-Rumsey (2018) found no or only a weakly significant impact of higher reserve requirements on credit growth, and therefore, on the risk assumed.

The effectiveness of countercyclical capital requirements, DSTI lending criteria and of the risk-weights applied to housing loans is confirmed when we analyze the impact of the whole set of housing measures (model 3) and of the 
individual housing measures on bank risk-taking (models 8 to 11). Kuttner and Shim (2016) and Akinci and Olmstead-Rumsey (2018) recognize the positive effects of DSTI ratios in reducing the credit housing growth and the risks associated with it, by cutting the riskier borrowers.

Loan loss provisioning measure has a negative, but statistically insignificant impact on individual risk in models (1) and (3) when the impact of this measure is assessed together with the other housing and general measures. Model (9) presents the output for loan loss provisioning measure taken individually. In this situation, the impact becomes positive and statistically significant, the provisioning on nonperforming loans generating an increase of bank risk-taking and, implicitly, the manifestation of moral hazard. Bouvatier and Lepetit (2012) sustain the initiative of Basel Committee for the implementation of a forward-looking provisioning system to address procyclicality, taking into account the expected losses.

We also examined the impact of macroprudential measures on banks' individual risk using $D T D$ as dependent variable. Higher levels of $D T D$ indicator are associated with enhanced stability of banks thus a positive coefficient corresponds to lower individual risk-taking (beneficial effect), while a negative coefficient is associated with increased risk-taking (harmful effect). Results depicted in Appendix D show that a significant reduction in banks' exposure to systemic risk is associated with stronger capital requirements, sector capital buffers, countercyclical capital requirements, loan loss provisioning and DSTI lending criteria, confirming the previous empirical output. ${ }^{7}$

\subsection{Robustness Checks}

We checked the robustness of our results by employing several alternative specifications (Table 6). First, we run the regression without macro and market specific controls. Models 1 and 2 present the empirical coefficients corresponding to the macroprudential policies' impact on systemic risk, while models 3 and 4 focus on banks' individual risk-taking. The findings confirm the effectiveness of additional capital holdings by banks to reduce the associated risks, as both sector capital buffers and countercyclical capital requirements for real estate loans remain negative and statistically significant. Also the DSTI criterion for real estate loans maintains its significance and beneficial effects in reducing banks' systemic importance and risktaking. Further, we include country fixed effects (models 5-8). In the third robustness check (models 9-12), we add to the baseline regression year fixed effects. Finally, we changed the clustering from country level to bank level (models 13-16). The results obtained remain very similar with the baseline specification, strengthening the importance to implement sector specific capital buffers, countercyclical capital requirements and borrower-based macroprudential measures.

As reverse causality among macroprudential policy measures and risk might affect our results we also consider the GMM estimation method. To control for

\footnotetext{
${ }^{7}$ We also investigated the impact of macroprudential policies on banks' Z-score, a widely used insolvency measure based only on accounting data. Z-score reports banks' return on assets and capitalization to the standard deviation of return on assets, comparing the capital buffer with the potential risk of default. Its interpretation is similar with DTD, higher values indicating higher distance from the default point, thus lower risk taking. Results presented in Appendix E are in line with the main findings.
} 
potential endogeneity we employ the First Difference GMM estimator of Arellano and Bond (1991). The general prudential measures and housing specific policies are considered endogenous and instrumented with lagged values in the first difference equation. The bank level and country level controls are considered exogenous, being instrumented with their level.

Specifications presented in Table 7 show that policy measures based on sector capital buffers, countercyclical capital requirements and DSTI lending criteria could significantly reduce banks' systemic importance as well as their risk taking, confirming thus the robustness of the findings obtained using the OLS method. Appendix F, which presents the effect of each macroprudential measure separately, shows similar results.

The validity of the instrumental variables set is confirmed by the Hansen $\mathbf{J}$ statistic for most models in Table 7 (with the exception of columns 2 and 5). The null hypothesis of the Hansen test is that the instruments are not correlated with the residuals. For the models shown in Table (7) we use as instruments the lags of the macroprudential variables from 1 to $5^{8}$, while for the models presented in Appendix E we use as instruments all possible further lags. ${ }^{9}$

Finally, we re-run the empirical specifications using a restrictive sample of banks from Europe. Results presented in Appendix G show that the main findings are very similar for European banks in terms of sign, magnitude and significance.

\footnotetext{
${ }^{8} \mathrm{We}$ comply with the rule that he number of instruments should be below the number of cross-sections.

${ }^{9}$ We used a collapse option to reduce the number of instruments to the minimum.
} 


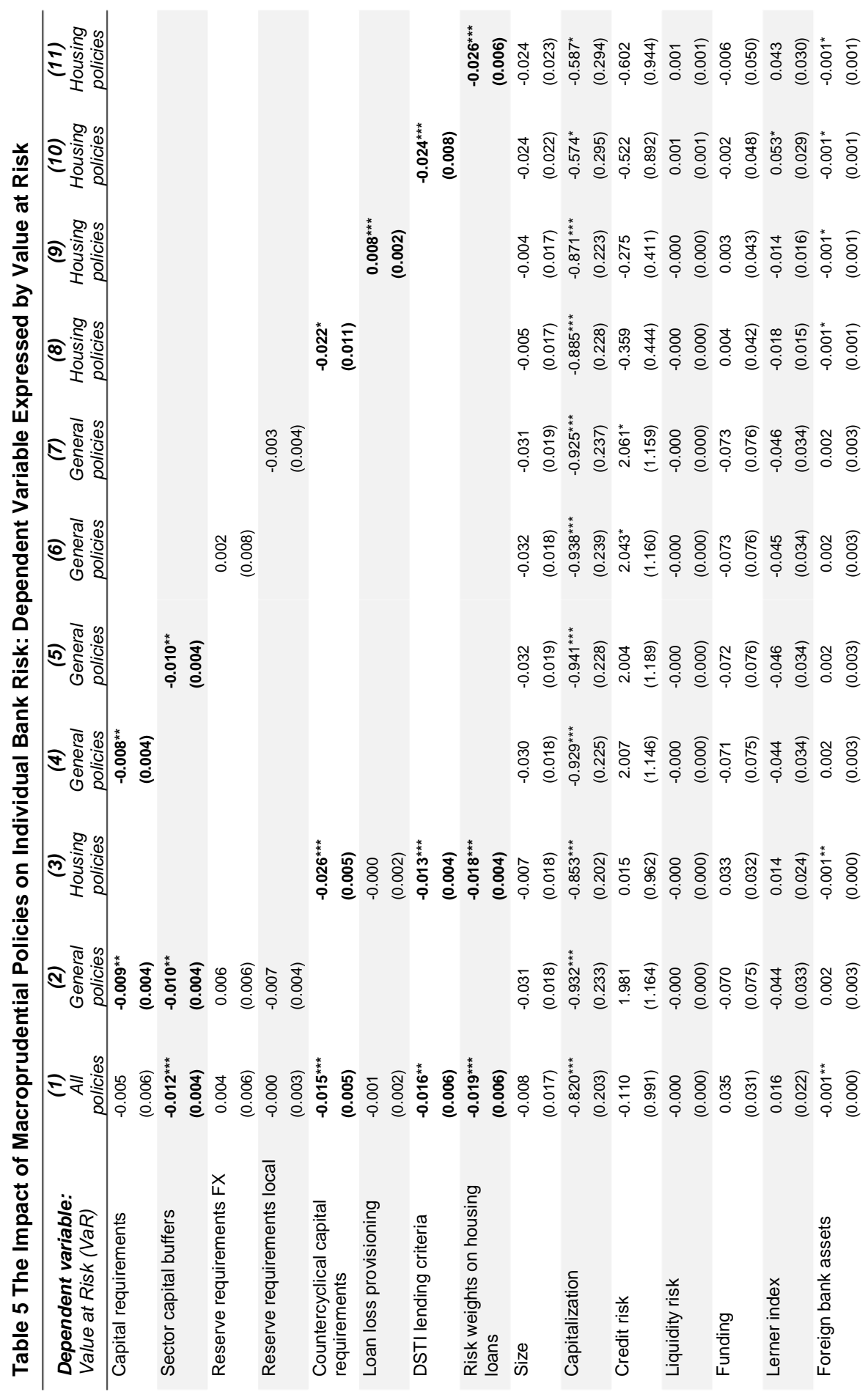




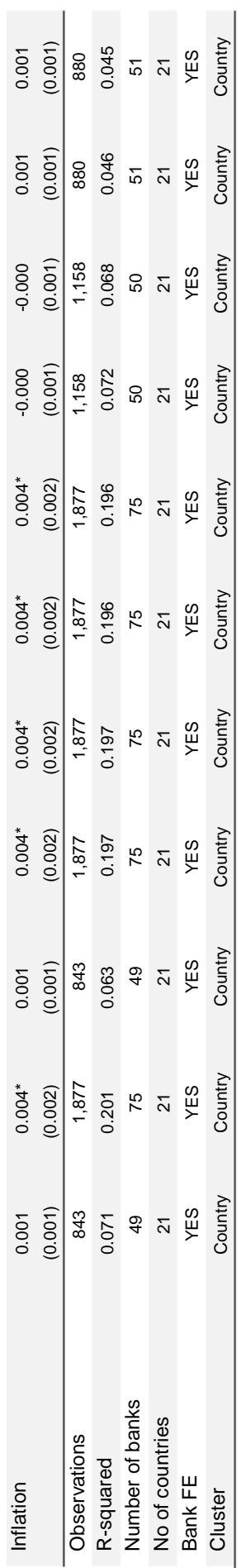

Finance a úvěr-Czech Journal of Economics and Finance, 68, 2018, no. 3 
Table 6 The Impact of Macroprudential Policies on Systemic Risk and Individual Risk: Robustness Assessment

\section{Part 1}

\begin{tabular}{|c|c|c|c|c|c|c|c|c|}
\hline \multirow{3}{*}{ Variables } & \multicolumn{3}{|c|}{ Without macro controls } & & \multirow[t]{2}{*}{ B. } & \multicolumn{2}{|c|}{ With country FE } & \multirow{3}{*}{$\frac{(8)}{D T D}$} \\
\hline & (1) & (2) & (3) & (4) & & (6) & (7) & \\
\hline & CoVaR & MES & VaR & DTD & CoVaR & MES & VaR & \\
\hline Capital requirements & $\begin{array}{l}-0.001 \\
(0.002)\end{array}$ & $\begin{array}{c}0.000 \\
(0.005)\end{array}$ & $\begin{array}{l}-0.007 \\
(0.006)\end{array}$ & $\begin{array}{l}-0.156 \\
(0.138)\end{array}$ & $\begin{array}{c}0.001 \\
(0.003)\end{array}$ & $\begin{array}{c}0.002 \\
(0.005)\end{array}$ & $\begin{array}{c}0.004 \\
(0.005)\end{array}$ & $\begin{array}{l}-0.081 \\
(0.141)\end{array}$ \\
\hline Sector capital buffers & $\begin{array}{l}-0.004^{* \star *} \\
(0.001)\end{array}$ & $\begin{array}{l}-0.006^{* * *} \\
(0.002)\end{array}$ & $\begin{array}{r}-0.011^{* * *} \\
(0.003)\end{array}$ & $\begin{array}{c}0.028 \\
(0.118)\end{array}$ & $\begin{array}{l}-0.003^{* * *} \\
(0.001)\end{array}$ & $\begin{array}{l}-0.006^{* *} \\
(0.002)\end{array}$ & $\begin{array}{l}-0.006^{* *} \\
(0.002)\end{array}$ & $\begin{array}{l}0.067 \\
(0.129)\end{array}$ \\
\hline $\begin{array}{l}\text { Reserve } \\
\text { requirements FX }\end{array}$ & $\begin{array}{l}-0.001 \\
(0.004)\end{array}$ & $\begin{array}{l}-0.003 \\
(0.007)\end{array}$ & $\begin{array}{c}0.005 \\
(0.007)\end{array}$ & $\begin{array}{l}0.401^{* *} \\
(0.138)\end{array}$ & $\begin{array}{c}0.002 \\
(0.004)\end{array}$ & $\begin{array}{c}0.002 \\
(0.007)\end{array}$ & $\begin{array}{l}0.015^{*} \\
(0.007)\end{array}$ & $\begin{array}{l}0.297^{* *} \\
(0.112)\end{array}$ \\
\hline $\begin{array}{l}\text { Reserve } \\
\text { requirements local }\end{array}$ & $\begin{array}{l}0.000 \\
(0.003)\end{array}$ & $\begin{array}{l}-0.001 \\
(0.005)\end{array}$ & $\begin{array}{l}-0.001 \\
(0.004)\end{array}$ & $\begin{array}{l}-0.035 \\
(0.173)\end{array}$ & $\begin{array}{l}-0.002 \\
(0.003)\end{array}$ & $\begin{array}{l}-0.005 \\
(0.006)\end{array}$ & $\begin{array}{l}-0.013^{* *} \\
(0.005)\end{array}$ & $\begin{array}{l}-0.012 \\
(0.144)\end{array}$ \\
\hline $\begin{array}{l}\text { Countercyclical } \\
\text { capital requirements }\end{array}$ & $\begin{array}{l}-0.012^{\star \star \star} \\
(0.001)\end{array}$ & $\begin{array}{l}-0.018^{* * *} \\
(0.002)\end{array}$ & $\begin{array}{c}-0.020^{* * *} \\
(0.003)\end{array}$ & $\begin{array}{l}-0.001 \\
(0.095)\end{array}$ & $\begin{array}{l}-0.015^{* \star *} \\
(0.002)\end{array}$ & $\begin{array}{l}-0.023^{* * *} \\
(0.003)\end{array}$ & $\begin{array}{c}-0.030^{* * *} \\
(0.007)\end{array}$ & $\begin{array}{l}0.055 \\
(0.169)\end{array}$ \\
\hline $\begin{array}{l}\text { Loan loss } \\
\text { provisioning }\end{array}$ & $\begin{array}{c}0.001 \\
(0.001)\end{array}$ & $\begin{array}{l}-0.001 \\
(0.002)\end{array}$ & $\begin{array}{l}-0.000 \\
(0.002)\end{array}$ & $\begin{array}{l}-0.446^{\star \star *} \\
(0.040)\end{array}$ & $\begin{array}{l}-0.003 \\
(0.003)\end{array}$ & $\begin{array}{l}-0.008 \\
(0.005)\end{array}$ & $\begin{array}{l}-0.006^{* *} \\
(0.003)\end{array}$ & $\begin{array}{l}-0.261^{*} \\
(0.132)\end{array}$ \\
\hline DSTI lending criteria & $\begin{array}{l}-0.008^{\star \star \star *} \\
(0.002)\end{array}$ & $\begin{array}{l}-0.013^{* \star *} \\
(0.003)\end{array}$ & $\begin{array}{c}-0.014^{\star \star *} \\
(0.006)\end{array}$ & $\begin{array}{l}0.077 \\
(0.084)\end{array}$ & $\begin{array}{l}-0.007^{* *} \\
(0.003)\end{array}$ & $\begin{array}{l}-0.010^{*} \\
(0.005)\end{array}$ & $\begin{array}{l}-0.010 \\
(0.006)\end{array}$ & $\begin{array}{l}0.055 \\
(0.166)\end{array}$ \\
\hline $\begin{array}{l}\text { Risk weights on } \\
\text { housing loans }\end{array}$ & $\begin{array}{l}-0.000 \\
(0.001)\end{array}$ & $\begin{array}{c}0.000 \\
(0.001)\end{array}$ & $\begin{array}{c}-0.018^{* * *} \\
(0.005)\end{array}$ & $\begin{array}{c}0.083 \\
(0.063)\end{array}$ & $\begin{array}{c}0.000 \\
(0.001)\end{array}$ & $\begin{array}{c}0.001 \\
(0.001)\end{array}$ & $\begin{array}{l}-0.011^{*} \\
(0.006)\end{array}$ & $\begin{array}{l}0.127^{*} \\
(0.064)\end{array}$ \\
\hline Size & $\begin{array}{l}-0.030^{* * *} \\
(0.009)\end{array}$ & $\begin{array}{l}-0.057^{* * *} \\
(0.015)\end{array}$ & $\begin{array}{l}-0.014 \\
(0.018)\end{array}$ & $\begin{array}{c}0.468 \\
(0.416)\end{array}$ & $\begin{array}{c}-0.023^{* * *} \\
(0.008)\end{array}$ & $\begin{array}{l}-0.047^{* * *} \\
(0.013)\end{array}$ & $\begin{array}{l}-0.005 \\
(0.013)\end{array}$ & $\begin{array}{c}0.306 \\
(0.189)\end{array}$ \\
\hline Capitalization & $\begin{array}{l}-0.616^{\star \star \star} \\
(0.145)\end{array}$ & $\begin{array}{l}-1.044^{* \star \star} \\
(0.200)\end{array}$ & $\begin{array}{c}-0.890^{* \star *} \\
(0.229)\end{array}$ & $\begin{array}{l}35.434^{* \star *} \\
(6.586)\end{array}$ & $\begin{array}{l}-0.484^{\star \star \star *} \\
(0.105)\end{array}$ & $\begin{array}{l}-0.829^{\star \star \star} \\
(0.146)\end{array}$ & $\begin{array}{l}-0.746^{*} \\
(0.358)\end{array}$ & $\begin{array}{l}30.171^{\star \star \star *} \\
(3.385)\end{array}$ \\
\hline Credit risk & $\begin{array}{c}0.540 \\
(0.434)\end{array}$ & $\begin{array}{l}1.404 \\
(0.833)\end{array}$ & $\begin{array}{l}-0.229 \\
(1.065)\end{array}$ & $\begin{array}{l}-19.433 \\
(16.047)\end{array}$ & $\begin{array}{r}0.775^{*} \\
(0.402)\end{array}$ & $\begin{array}{l}1.907^{* *} \\
(0.805)\end{array}$ & $\begin{array}{c}0.774 \\
(0.624)\end{array}$ & $\begin{array}{l}-28.176^{*} \\
(13.735)\end{array}$ \\
\hline Liquidity risk & $\begin{array}{l}-0.000 \\
(0.000)\end{array}$ & $\begin{array}{l}-0.000 \\
(0.000)\end{array}$ & $\begin{array}{l}-0.000^{*} \\
(0.000)\end{array}$ & $\begin{array}{c}0.002 \\
(0.002)\end{array}$ & $\begin{array}{l}-0.000 \\
(0.000)\end{array}$ & $\begin{array}{l}-0.000 \\
(0.000)\end{array}$ & $\begin{array}{l}-0.000 \\
(0.000)\end{array}$ & $\begin{array}{c}0.002 \\
(0.003)\end{array}$ \\
\hline Funding & $\begin{array}{l}0.010^{*} \\
(0.005)\end{array}$ & $\begin{array}{l}0.024^{* *} \\
(0.008)\end{array}$ & $\begin{array}{c}0.039 \\
(0.029)\end{array}$ & $\begin{array}{l}-0.429 \\
(0.578)\end{array}$ & $\begin{array}{r}0.009^{*} \\
(0.004)\end{array}$ & $\begin{array}{l}0.021^{* *} \\
(0.007)\end{array}$ & $\begin{array}{l}0.034 \\
(0.024)\end{array}$ & $\begin{array}{l}-0.411 \\
(0.514)\end{array}$ \\
\hline Lerner index & & & & & & & & \\
\hline $\begin{array}{l}\text { Foreign bank assets } \\
\text { Inflation }\end{array}$ & & & & & & & & \\
\hline Observations & 906 & 906 & 906 & 863 & 906 & 906 & 906 & 863 \\
\hline R-squared & 0.090 & 0.091 & 0.063 & 0.198 & 0.114 & 0.116 & 0.106 & 0.245 \\
\hline Number of banks & 53 & 53 & 53 & 51 & 53 & 53 & 53 & 51 \\
\hline No of countries & 21 & 21 & 21 & 21 & 21 & 21 & 21 & 21 \\
\hline Bank FE & YES & YES & YES & YES & YES & YES & YES & YES \\
\hline Year FE & NO & NO & NO & NO & NO & NO & NO & NO \\
\hline Country FE & NO & NO & NO & NO & YES & YES & YES & YES \\
\hline Cluster & Country & Country & Country & Country & Country & Country & Country & Country \\
\hline
\end{tabular}

\section{Part 2}

\begin{tabular}{|c|c|c|c|c|c|c|c|c|}
\hline \multirow{3}{*}{ Variables } & \multicolumn{3}{|c|}{ With year FE } & & \multirow{2}{*}{$D}$. & \multicolumn{2}{|c|}{ Bank level clustering } & \multirow{3}{*}{$\frac{(16)}{D T D}$} \\
\hline & (9) & (10) & (11) & (12) & & (14) & (15) & \\
\hline & CoVaR & MES & VaR & DTD & CoVar & MES & $V a R$ & \\
\hline Capital requirements & $\begin{array}{c}0.000 \\
(0.003)\end{array}$ & $\begin{array}{c}0.001 \\
(0.006)\end{array}$ & $\begin{array}{l}0.005 \\
(0.005)\end{array}$ & $\begin{array}{l}-0.032 \\
(0.160)\end{array}$ & $\begin{array}{l}-0.002 \\
(0.002)\end{array}$ & $\begin{array}{l}-0.002 \\
(0.004)\end{array}$ & $\begin{array}{l}-0.005 \\
(0.003)\end{array}$ & $\begin{array}{l}-0.096 \\
(0.098)\end{array}$ \\
\hline Sector capital buffers & $\begin{array}{l}-0.004^{* * *} \\
(0.001)\end{array}$ & $\begin{array}{c}-0.007^{* * *} \\
(0.002)\end{array}$ & $\begin{array}{l}-0.007^{\star *} \\
(0.003)\end{array}$ & $\begin{array}{c}0.088 \\
(0.140)\end{array}$ & $\begin{array}{l}-0.005^{\star \star \star *} \\
(0.001)\end{array}$ & $\begin{array}{l}-0.008^{* \star \star *} \\
(0.002)\end{array}$ & $\begin{array}{l}-0.012^{\star \star \star *} \\
(0.002)\end{array}$ & $\begin{array}{c}0.059 \\
(0.089)\end{array}$ \\
\hline $\begin{array}{l}\text { Reserve requirements } \\
\text { FX }\end{array}$ & $\begin{array}{c}0.001 \\
(0.003)\end{array}$ & $\begin{array}{c}0.002 \\
(0.007)\end{array}$ & $\begin{array}{l}0.012 \\
(0.007)\end{array}$ & $\begin{array}{l}0.352^{* * *} \\
(0.096)\end{array}$ & $\begin{array}{l}-0.000 \\
(0.003)\end{array}$ & $\begin{array}{l}-0.000 \\
(0.005)\end{array}$ & $\begin{array}{l}0.004 \\
(0.004)\end{array}$ & $\begin{array}{l}0.294^{* *} \\
(0.124)\end{array}$ \\
\hline $\begin{array}{l}\text { Reserve requirements } \\
\text { local }\end{array}$ & $\begin{array}{l}-0.002 \\
(0.003)\end{array}$ & $\begin{array}{l}-0.005 \\
(0.005)\end{array}$ & $\begin{array}{l}-0.012^{\star *} \\
(0.005)\end{array}$ & $\begin{array}{l}-0.105 \\
(0.148)\end{array}$ & $\begin{array}{l}-0.000 \\
(0.002)\end{array}$ & $\begin{array}{l}-0.002 \\
(0.003)\end{array}$ & $\begin{array}{l}-0.000 \\
(0.003)\end{array}$ & $\begin{array}{l}-0.010 \\
(0.079)\end{array}$ \\
\hline $\begin{array}{l}\text { Countercyclical } \\
\text { capital requirements }\end{array}$ & $\begin{array}{l}-0.013^{* * *} \\
(0.002)\end{array}$ & $\begin{array}{c}-0.020^{* \star *} \\
(0.003)\end{array}$ & $\begin{array}{l}-0.025^{\star *} \\
(0.008)\end{array}$ & $\begin{array}{l}-0.046 \\
(0.217)\end{array}$ & $\begin{array}{l}-0.009^{*} \\
(0.005)\end{array}$ & $\begin{array}{l}-0.012^{*} \\
(0.007)\end{array}$ & $\begin{array}{l}-0.015^{\star *} \\
(0.006)\end{array}$ & $\begin{array}{l}-0.146 \\
(0.230)\end{array}$ \\
\hline $\begin{array}{l}\text { Loan loss } \\
\text { provisioning }\end{array}$ & $\begin{array}{l}-0.002 \\
(0.003)\end{array}$ & $\begin{array}{l}-0.007 \\
(0.005)\end{array}$ & $\begin{array}{l}-0.006^{*} \\
(0.003)\end{array}$ & $\begin{array}{l}-0.360^{* * *} \\
(0.104)\end{array}$ & $\begin{array}{l}-0.002 \\
(0.001)\end{array}$ & $\begin{array}{l}-0.007^{* * *} \\
(0.002)\end{array}$ & $\begin{array}{l}-0.001 \\
(0.002)\end{array}$ & $\begin{array}{l}-0.328^{* * *} \\
(0.057)\end{array}$ \\
\hline DSTI lending criteria & $\begin{array}{l}-0.008^{* *} \\
(0.003)\end{array}$ & $\begin{array}{l}-0.012^{* *} \\
(0.005)\end{array}$ & $\begin{array}{l}-0.013^{*} \\
(0.006)\end{array}$ & $\begin{array}{c}0.133 \\
(0.160)\end{array}$ & $\begin{array}{l}-0.009^{* * *} \\
(0.002)\end{array}$ & $\begin{array}{l}-0.013^{* \star *} \\
(0.004)\end{array}$ & $\begin{array}{l}-0.016^{\star *} \\
(0.007)\end{array}$ & $\begin{array}{l}0.084 \\
(0.084)\end{array}$ \\
\hline $\begin{array}{l}\text { Risk weights on } \\
\text { housing loans }\end{array}$ & $\begin{array}{l}-0.001 \\
(0.001)\end{array}$ & $\begin{array}{l}-0.000 \\
(0.002)\end{array}$ & $\begin{array}{l}-0.013^{*} \\
(0.007)\end{array}$ & $\begin{array}{c}0.069 \\
(0.127)\end{array}$ & $\begin{array}{l}-0.003 \\
(0.002)\end{array}$ & $\begin{array}{l}-0.004 \\
(0.004)\end{array}$ & $\begin{array}{l}-0.019^{* * *} \\
(0.005)\end{array}$ & $\begin{array}{l}0.110 \\
(0.143)\end{array}$ \\
\hline Size & $\begin{array}{l}-0.024^{\star *} \\
(0.010)\end{array}$ & $\begin{array}{l}-0.044^{* *} \\
(0.017)\end{array}$ & $\begin{array}{l}-0.007 \\
(0.014)\end{array}$ & $\begin{array}{l}-0.121 \\
(0.171)\end{array}$ & $\begin{array}{l}-0.028^{\star * *} \\
(0.008)\end{array}$ & $\begin{array}{l}-0.047^{* * *} \\
(0.014)\end{array}$ & $\begin{array}{l}-0.008 \\
(0.016)\end{array}$ & $\begin{array}{l}-0.109 \\
(0.343)\end{array}$ \\
\hline Capitalization & $\begin{array}{l}-0.480^{* * *} \\
(0.106)\end{array}$ & $\begin{array}{c}-0.808^{* * *} \\
(0.153)\end{array}$ & $\begin{array}{l}-0.742^{* *} \\
(0.332)\end{array}$ & $\begin{array}{l}28.687^{* * *} \\
(3.080)\end{array}$ & $\begin{array}{l}-0.538^{* * *} \\
(0.114)\end{array}$ & $\begin{array}{l}-0.889^{* * *} \\
(0.177)\end{array}$ & $\begin{array}{l}-0.820^{* \star *} \\
(0.195)\end{array}$ & $\begin{array}{l}30.741^{* * *} \\
(5.634)\end{array}$ \\
\hline Credit risk & $\begin{array}{r}0.857^{*} \\
(0.401)\end{array}$ & $\begin{array}{l}1.983^{* *} \\
(0.793)\end{array}$ & $\begin{array}{c}0.710 \\
(0.571)\end{array}$ & $\begin{array}{l}-23.066 \\
(13.267)\end{array}$ & $\begin{array}{c}0.472 \\
(0.435)\end{array}$ & $\begin{array}{l}1.187 \\
(0.818)\end{array}$ & $\begin{array}{l}-0.110 \\
(0.781)\end{array}$ & $\begin{array}{l}-11.140 \\
(15.107)\end{array}$ \\
\hline Liquidity risk & $\begin{array}{c}0.000 \\
(0.000)\end{array}$ & $\begin{array}{c}0.000 \\
(0.000)\end{array}$ & $\begin{array}{l}-0.000 \\
(0.000)\end{array}$ & $\begin{array}{c}0.002 \\
(0.003)\end{array}$ & $\begin{array}{l}0.000 \\
(0.000)\end{array}$ & $\begin{array}{l}-0.000 \\
(0.000)\end{array}$ & $\begin{array}{l}-0.000 \\
(0.000)\end{array}$ & $\begin{array}{c}0.002 \\
(0.003)\end{array}$ \\
\hline Funding & $\begin{array}{c}0.009^{*} \\
(0.004)\end{array}$ & $\begin{array}{l}0.021^{* *} \\
(0.009)\end{array}$ & $\begin{array}{c}0.030 \\
(0.026)\end{array}$ & $\begin{array}{l}-0.330 \\
(0.437)\end{array}$ & $\begin{array}{c}0.009 \\
(0.008)\end{array}$ & $\begin{array}{c}0.021 \\
(0.016)\end{array}$ & $\begin{array}{c}0.035 \\
(0.028)\end{array}$ & $\begin{array}{l}-0.327 \\
(0.387)\end{array}$ \\
\hline Lerner index & $\begin{array}{c}0.008 \\
(0.011)\end{array}$ & $\begin{array}{c}0.011 \\
(0.015)\end{array}$ & $\begin{array}{c}0.014 \\
(0.018)\end{array}$ & $\begin{array}{l}-0.797 \\
(0.494)\end{array}$ & $\begin{array}{c}0.009 \\
(0.008)\end{array}$ & $\begin{array}{c}0.014 \\
(0.014)\end{array}$ & $\begin{array}{c}0.016 \\
(0.020)\end{array}$ & $\begin{array}{l}-0.782 \\
(0.518)\end{array}$ \\
\hline Foreign bank assets & $\begin{array}{c}-0.001^{* * \star} \\
(0.000)\end{array}$ & $\begin{array}{l}-0.000 \\
(0.000)\end{array}$ & $\begin{array}{l}-0.001^{* * *} \\
(0.000)\end{array}$ & $\begin{array}{l}-0.029 \\
(0.027)\end{array}$ & $\begin{array}{l}-0.001^{\star * *} \\
(0.000)\end{array}$ & $\begin{array}{l}-0.000 \\
(0.000)\end{array}$ & $\begin{array}{l}-0.001^{* * *} \\
(0.000)\end{array}$ & $\begin{array}{l}-0.029 \\
(0.022)\end{array}$ \\
\hline Inflation & $\begin{array}{c}0.001 \\
(0.001)\end{array}$ & $\begin{array}{c}0.002 \\
(0.002)\end{array}$ & $\begin{array}{l}-0.000 \\
(0.002)\end{array}$ & $\begin{array}{c}0.008 \\
(0.064)\end{array}$ & $\begin{array}{l}0.002^{\star * *} \\
(0.001)\end{array}$ & $\begin{array}{l}0.004^{* * *} \\
(0.001)\end{array}$ & $\begin{array}{c}0.001 \\
(0.001)\end{array}$ & $\begin{array}{l}-0.118^{* * *} \\
(0.030)\end{array}$ \\
\hline Observations & 843 & 843 & 843 & 800 & 843 & 843 & 843 & 800 \\
\hline R-squared & 0.117 & 0.112 & 0.104 & 0.266 & 0.106 & 0.101 & 0.071 & 0.241 \\
\hline Number of banks & 49 & 49 & 49 & 47 & 49 & 49 & 49 & 47 \\
\hline No of countries & 21 & 21 & 21 & 21 & 21 & 21 & 21 & 21 \\
\hline Bank FE & YES & YES & YES & YES & YES & YES & YES & YES \\
\hline Year FE & YES & YES & YES & YES & NO & NO & NO & NO \\
\hline Country FE & NO & NO & NO & NO & NO & NO & NO & NO \\
\hline Cluster & Country & Country & Country & Country & Bank & Bank & Bank & Bank \\
\hline
\end{tabular}




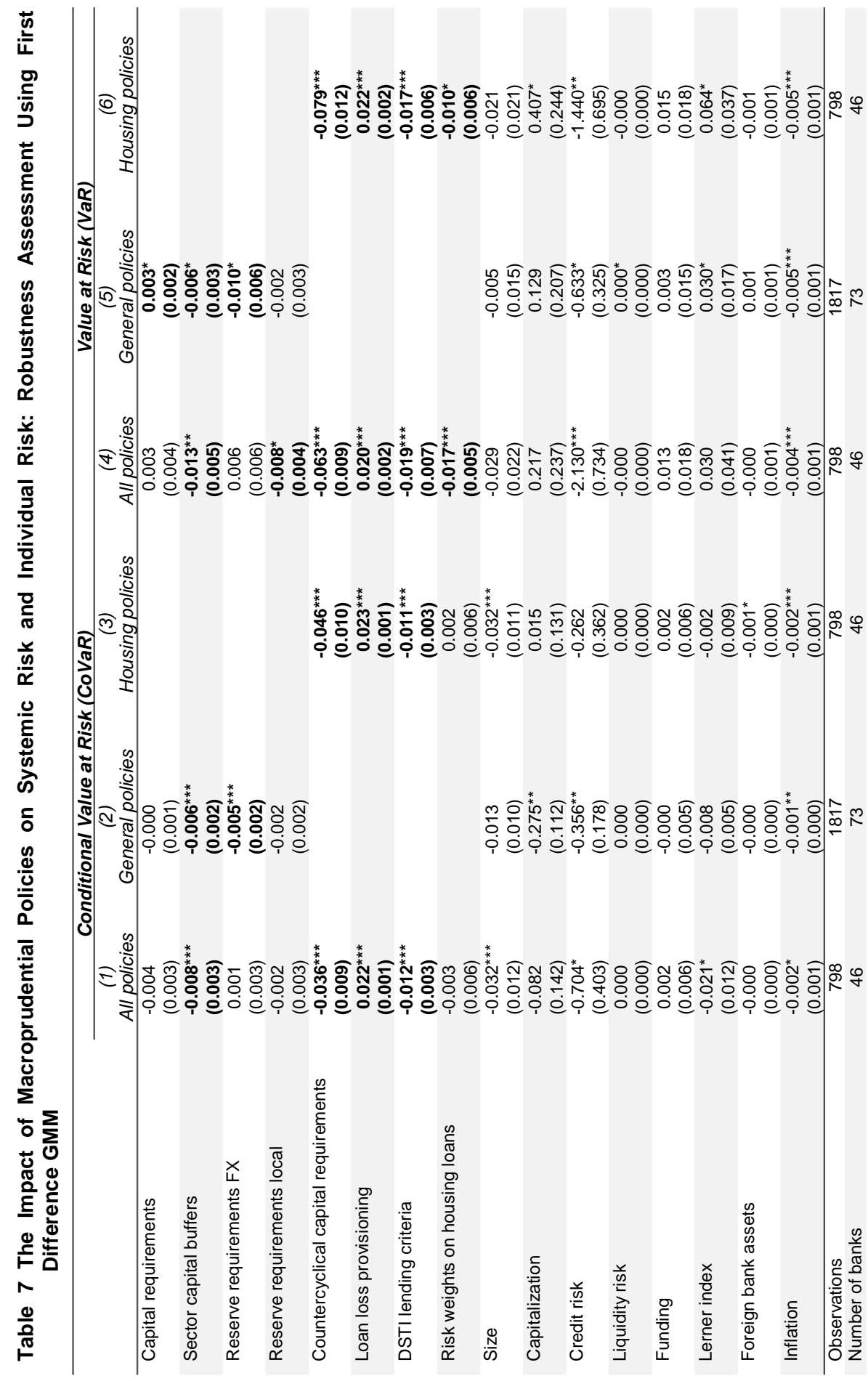




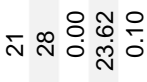

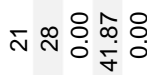

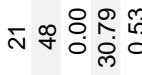

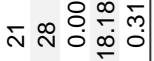

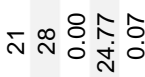

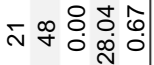

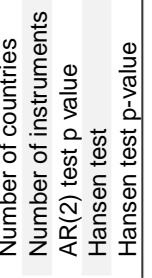




\subsection{The Impact of Macroprudential Policies on Risk Across Bank and Market Level Characteristics}

This section presents the empirical results on the impact of macroprudential measures adopted by central authorities on systemic risk and risk-taking behavior taken across different banks and banking systems. Using the difference-in-difference methodology we assess if the impact of the adopted macroprudential measures is amplified or diminished by the size of banks or banking sector characteristics like foreign assets holdings, competition and independence of supervisory authority. We analyze the impact of general and housing policy instruments on all measures of risk (i.e., systemic risk estimated through CoVaR and $M E S$, and, individual risk estimated through $\operatorname{VaR}$ and $D T D$ ). The empirical output reported corresponds to the baseline model.

First, we examine the interactive effects of general and housing macroprudential measures and banks' size on their systemic importance and individual risk. A number of papers show that smaller banks pose a greater contribution to systemic risk than larger ones. Larger banks are less systemic important due to the fact that they developed various risk management tools, allowing them to manage efficiently the risks assumed. This could be the result of better diversification possibilities as larger banks have access to more credit markets and can better hedge credit risk through credit derivative transactions (Behr et al., 2010). Results presented in Table 8 show that reserve requirements (for foreign and local denominated liabilities) are beneficial in reducing the systemic importance of large banks (models 1-2, and models 5-6). This conclusion applies also to the impact of reserve requirements for FX liabilities on individual risk as shown in model 3 . The coefficient associated with the link between reserve requirements for local currencydenominated accounts and $V a R$ has a negative sign associated, but it is insignificant (model 7). To highlight the economic relevance of our estimates we calculate the difference in semi-elasticities for small and large banks $\left(25^{\text {th }}\right.$ versus $75^{\text {th }}$ percentile, corresponding to a logarithmic value of the total assets of 24.7 versus 27.1). Tightening FX reserve requirements reduces banks contribution to systemic risk (CoVaR) of large banks by 30.5 percent more than of small banks. The effect on individual risk ( $\mathrm{VaR})$ translates to 31.7 percent. In case of local reserve requirements the impact on systemic risk (CoVaR) is associated with a 15.3 percent higher decrease. ${ }^{10}$ As for the risk-weights applied to housing loans, our results suggest that tightening actions associated with this policy conducts to a decrease in banks' systemic importance for large banks (models 9 and 10). In contrast, the distance to default of large banks decreases in countries that register tightening events of risk weights on real estate loans, indicating an enhancement of the risk-taking (model 12).

Next, we assess the interacting effects between the international activity of banks and risk. The empirical output from Table 9 highlight that banks from countries with a large share of foreign assets in total banking system assets, that conducted tightening events of reserve requirements for both in local and foreign currencies denominated liabilities, increased their systemic importance and individual risk (Table 9, models 1 to 8 ). The associated semi-elasticities are 3.7

\footnotetext{
10 The semi-elasticities are calculated based on the average value of CoVaR (4.6 percent) and the average value of $\operatorname{VaR}$ (11.8 percent).
} 
percent in case of CoVaR (model 1) and 4.5 percent in case of VaR (model 3). ${ }^{11}$ Tightening reserve requirements reduces banks' contribution to systemic risk $(\mathrm{CoVaR})$ in systems with low international activity by 3.7 percent more than in systems with high shares of FX assets, while the VaR wil be reduced by 4.5 percent more. Turning to housing macroprudential measures, we found a significant impact on banks' individual risk in countries with a large share of foreign assets. Banks from these countries that experienced tightening of countercyclical capital requirements increased their risk-taking (model 11) and reduced their distance to default (as the coefficient on Countercyclical capital requirements $\times$ Foreign assets in model 12 is negative and significant). An opposing effect is found for DSTI lending criteria on real estate loans (models 15 and 16). Greater restrictions for this ratio present a beneficial effect in reducing the incentives to take on more risk of banks from countries with high international presence in the banking sector.

Competition between financial institutions can lead to excessive risk-taking creating financial instability that should be controlled by macroprudential policy (IMF, 2013). On the other side, high levels of competition may determine the possibility of mergers and takeovers between banks that creates „too big to fail" institutions hard to be controlled by macroprudential authorities. Results presented in Table 10 show that for less competitive banking systems (with associated higher values of the Lerner index), strong macroprudential measures are not effective in limiting the incentives of banks to take on more risk and to decrease their systemic importance (Table 10). In fact, banks from less competitive banking markets that tightened the reserve requirements on accounts denominated in local currencies (models 5-8) and the countercyclical capital requirements (models 9-12) increased their contribution to systemic risk and individual risk-taking. Tightening domestic reserve requirements reduces banks contribution to systemic risk (CoVaR) of banks from highly competitive systems by 28.6 percent more than of banks from lowly competitive banking systems (model 5). Regarding countercyclical capital requirements the impact is associated with a reduction of banks' CoVaR by 51.7 percent more in case of highly competitive banking systems in comparison with lowly competitive ones (model 9). ${ }^{12}$ Tightening the sector specific capital buffers significantly increase banks behavior to take on more risk (as suggested by the positive coefficient on Sector capital buffers $\times$ Competition in model 3) and reduce the distance to default (model 4) in less competitive markets, while their impact on systemic importance is not significant. DSTI lending criteria also has harmful effects for less competitive markets, increasing banks' systemic importance (model 13).

In a further analysis, we consider the overall independence of supervisory authority index proposed by the Brath et al. (2013) that reflects the degree to which the supervisory authority is independent from the government and legally protected from the banking industry. Higher values indicate greater independence. Table 11 depicts that the general macroprudential measures that prove to be effective for

\footnotetext{
11 The differences in semi-elasticities are calculated for countries with low versus high international activity (we compare the $25^{\text {th }}$ versus $75^{\text {th }}$ percentile, corresponding to a share of foreign assets in total assets of 6 percent versus 18 percent).

12 We compare the $25^{\text {th }}$ versus $75^{\text {th }}$ percentile of the Lerner index corresponding to a value of 0.198 versus 0.320 .
} 
banking systems with high degree of supervisory authority's independence from the government are stronger capital requirements. The coefficient on the interaction term Capital requirements $\times S A I$ is negative and significant for CoVaR (model 1), MES (model 2) and $\operatorname{VaR}$ (model 3) and positive for DTD (model 4), suggesting a reduction in banks' systemic importance and DTD. In contrast, tightening the sector capital buffers and reserve requirements for accounts denominated in local currency will increase the systemic and individual risk for banks from countries with greater independence for supervisory authorities (models 13-16).

Regarding the housing related macroprudential policies, results show an adverse and significant impact (Table 12). Countercyclical capital requirements, loan loss provisions and risk-weights applied to housing loans increase the systemic importance and risk-taking incentives of banks from countries with greater independence for supervisory authorities.

To sum up, the macroprudential measures that proved their efficiency in limiting banks' risk-taking and systemic importance are heterogeneous across banks' size and banking markets' characteristics like the share of foreign assets, the competition or the supervisory authority's degree of independence. Capital related policies proved more effective in controlling the contribution of banks to systemic risk than instruments that target the borrowers (like DSTI for example). Robustness checks similar to those run in section 5.1.3 confirm the validity of the findings. 


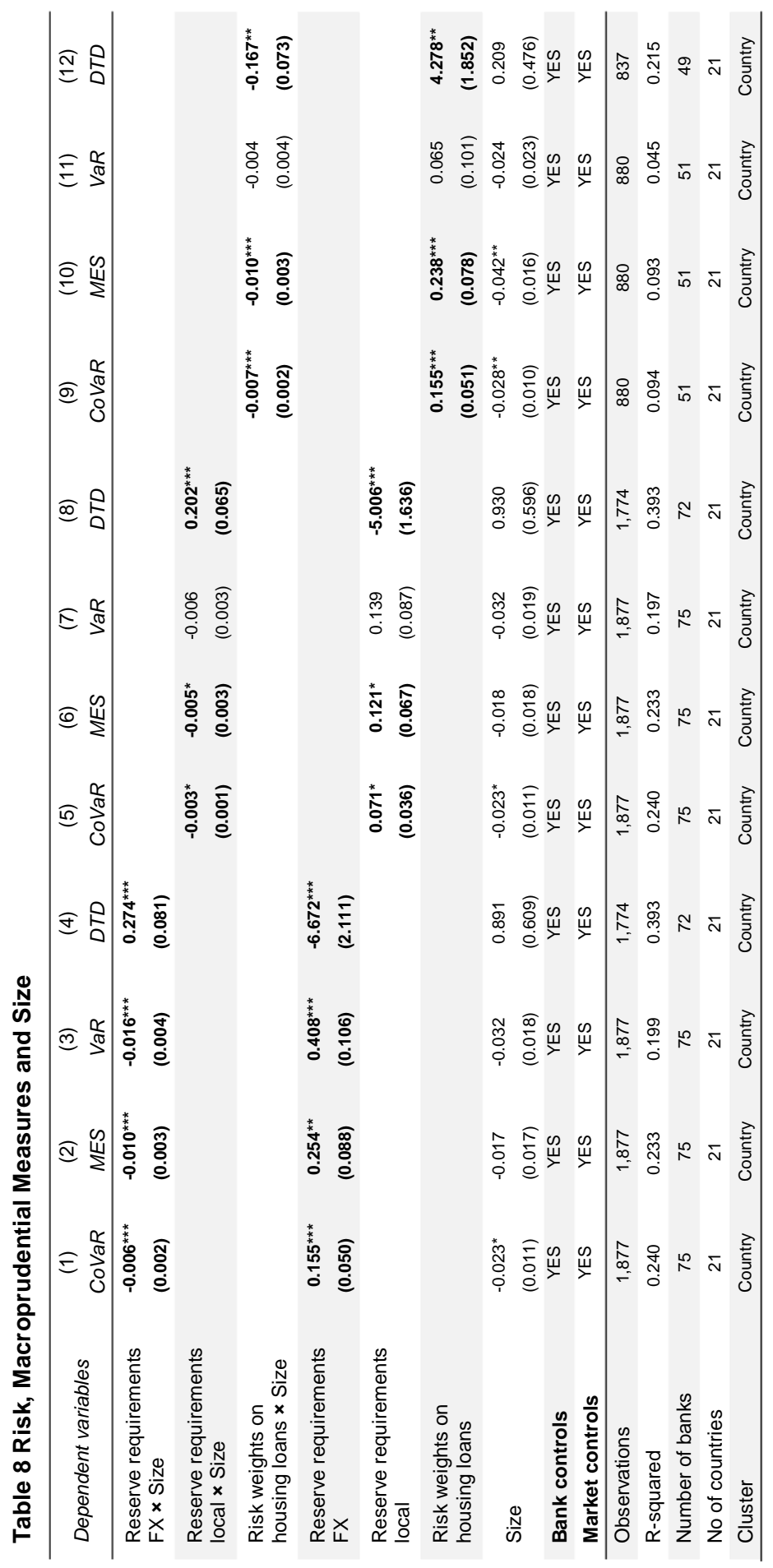




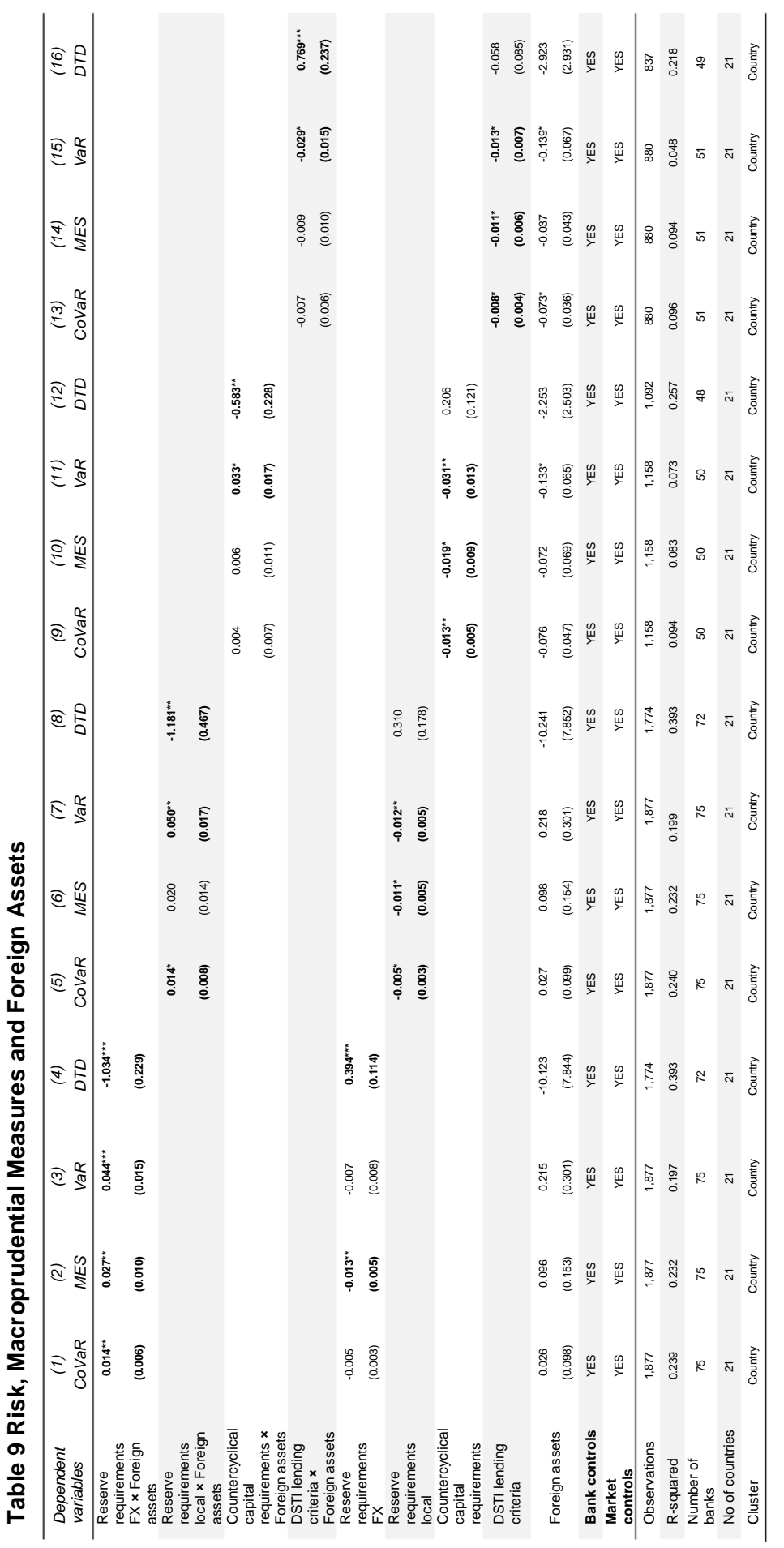

Finance a úvěr-Czech Journal of Economics and Finance, 68, 2018, no. 3 


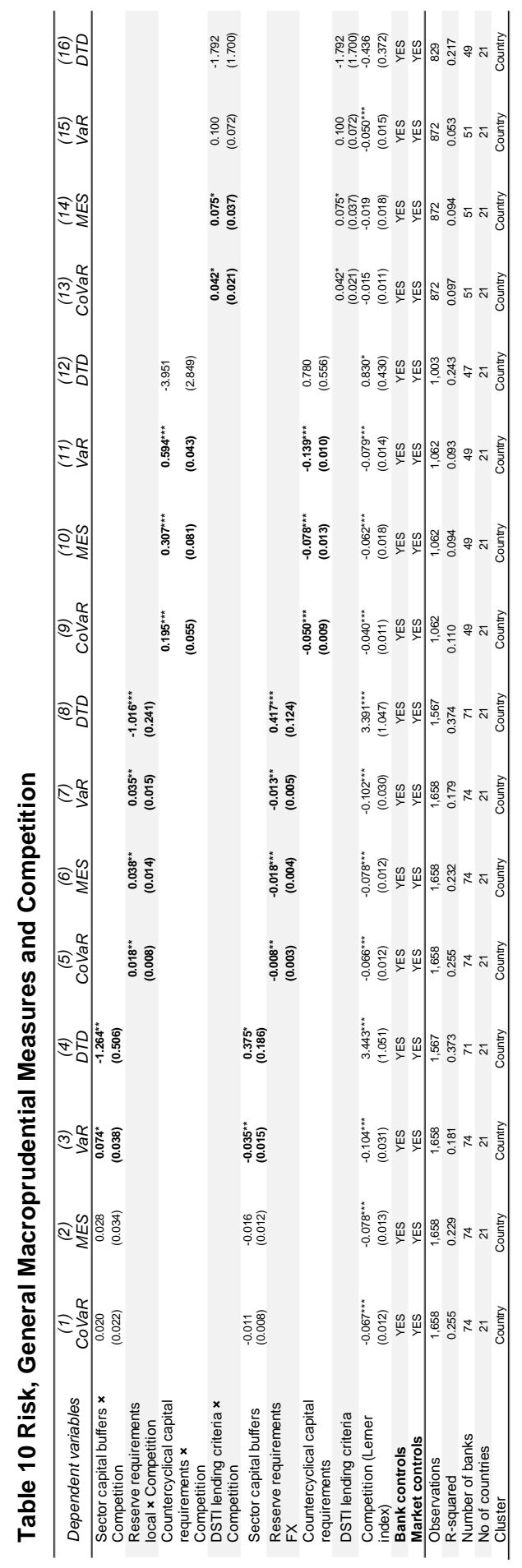




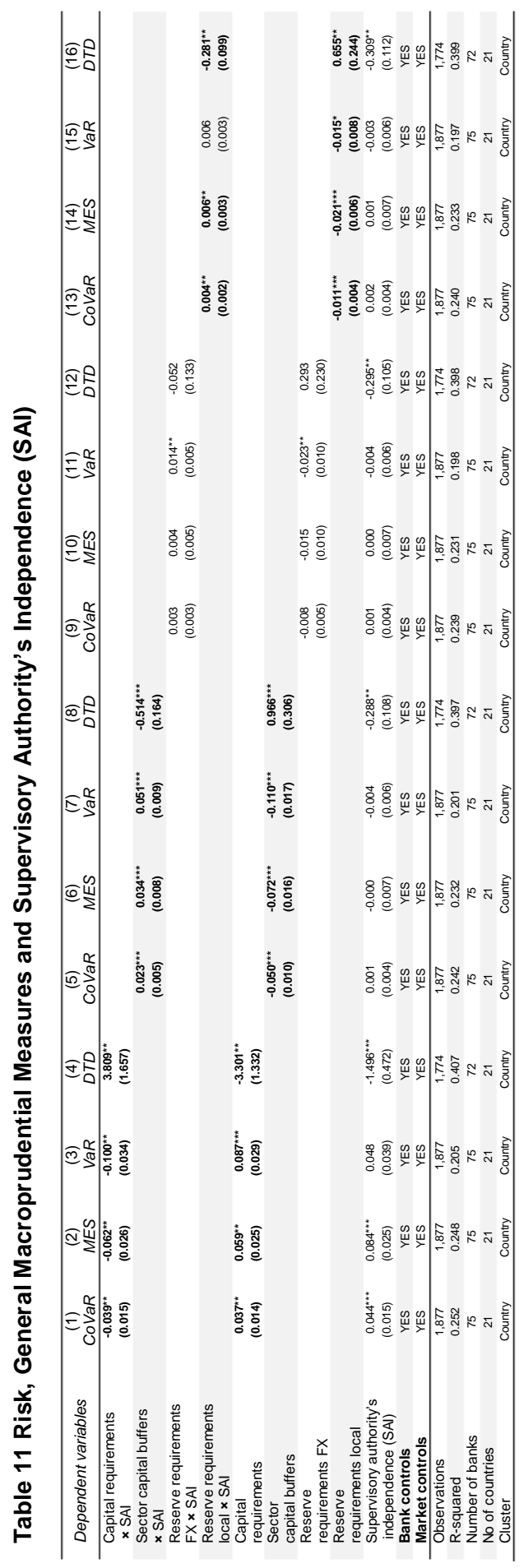

Finance a úvěr-Czech Journal of Economics and Finance, 68, 2018, no. 3 


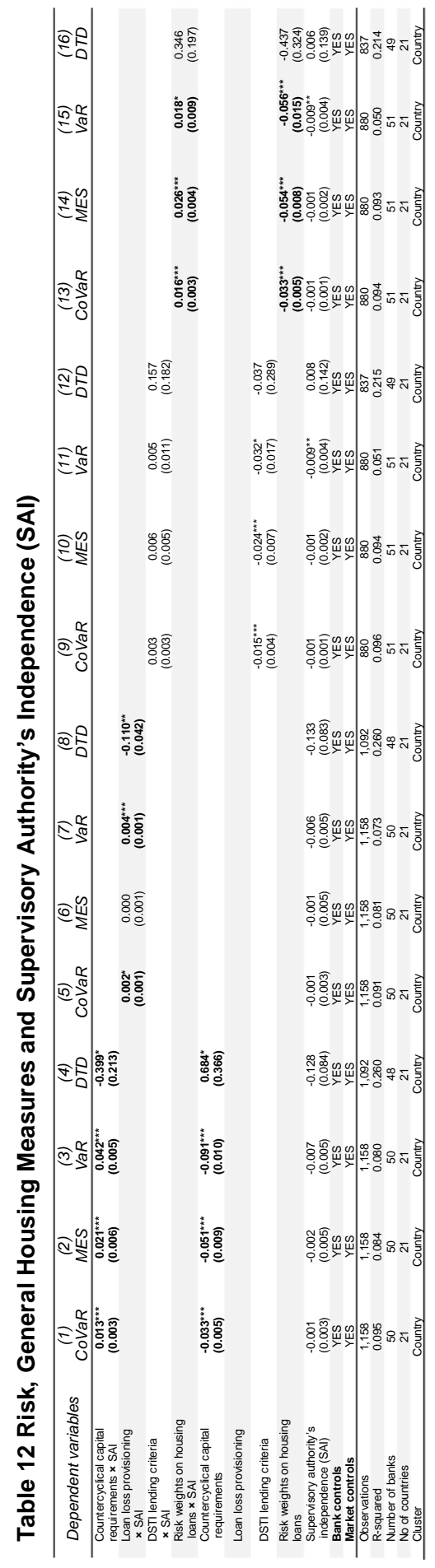




\section{Conclusion}

In this paper, we assess whether macroprudential policies implemented by supervisory authorities have a significant impact on banks' contribution to systemic risk and their risk-taking incentives. We consider a large set of general and housing related policies that affected 95 banks from 21 countries from Europe and North America during 2008 to 2014. The general macroprudential tools include capital requirements, sector specific capital buffers and reserve requirements on foreign and local currency denominated accounts. The real estate specific macroprudential policies consist of countercyclical capital requirements, loan loss provisioning, DSTI lending criteria and risk weights on housing loans.

Overall, empirical findings indicate that general and sector specific capital buffers, along with housing countercyclical capital requirements and DSTI lending criteria significantly reduce banks' systemic importance and their individual risktaking. For real estate loans loss provisioning we find a harmful effect as tighter rules enhance the level of risk.

In addition, we provide empirical evidence that the nexus between macroprudential policies and banks' risk is shaped through several bank and market level channels. The contribution to systemic risk of large banks can be decreased through higher reserve requirements on accounts denominated in foreign and local currencies and higher risk-weights applied to housing loans. The resilience of financial institutions from banking systems that hold important shares of foreign assets can be enhanced by loosening the reserve requirements and the countercyclical capital requirements. In case of competitive banking markets, lower reserve requirements on domestic currency denominated accounts, lower countercyclical capital requirements and relaxed DSTI lending criteria are efficient in controlling systemic risk. In countries with higher degree of independence of supervisory authority, regulators should tighten the general capital requirements, but reduce the sector specific and countercyclical buffers to enhance the stability of the banking sector.

Our results provide useful implications for policymakers. During crisis periods, when most of economies threatened by negative contagion spillover effects among financial institutions, the level of systemic risk could be controlled through macroprudential tools like reserve requirements, countercyclical capital requirements, DSTI lending criteria and risk-weights applied to housing loans. The macroprudential policies can also support banks to adjust their risk taking during turbulent periods, especially the real estate specific ones. However, when designing regulatory frameworks based on macroprudential tools, it is important for financial supervisors to consider the channels that could influence the relationship between policy measures and risk. Being on a direction of tightening/loosening general and housing policy measures has more potential when accounting for characteristics like size, international activity, competition and supervisory authority's independence. 


\section{REFERENCES}

Acemoglu D, Ozdaglar A, Tahbaz-Salehi A (2015): Systemic Risk and Stability in Financial Networks. American Economic Review, 105(2):564-608.

Acharya V, Pedersen L, Philippon T, Richardson M (2017): Measuring Systemic Risk. The Review of Financial Studies, 30(1):2-47.

Adrian T, Brunnermeier M (2016): CoVaR. American Economic Review, 106(7):1705-1742.

Adrian T, Shin H (2010): Liquidity and Leverage. Journal of Financial Intermediation, 19(3):418437.

Akinci O, Olmstead-Rumsey J (2018): How Effective are Macroprudential Policies? An Empirical Investigation. Journal of Financial Intermediation, 33:33-57.

Altunbas Y, Binici M, Gambacorta L (2018): Macroprudential Policy and Bank Risk. Journal of International Money and Finance, 81:203-220.

Anginer D, Demirguc-Kunt A, Zhu M (2014a): How Does Competition Affect Bank Systemic Risk? Journal of Financial Intermediation, 23(1):1-26.

Anginer D, Demirguc-Kunt A, Zhu M (2014b): How Does Deposit Insurance Affect Bank Risk? Evidence from the Recent Crisis. Journal of Banking and Finance, 48:312-321.

Arellano M, Bond S (1991): Some Tests of Specification for Panel Data: Monte Carlo Evidence and an Application to Employment Equations. Review of Economic Studies, 38(2):277-297.

Avdjilev S, Koch C, McGuire P, von Peter G (2017): International Prudential Policy Spillovers: A Global Perspective. International Journal of Central Banking, 13(S1):5-33.

Aydinbas YC, Hardt C, Rzayev J, Soker M, Taylor T, Walker D, Zhao P (2015): Frameworks for Implementing Macroprudetial Policy. New York: The Federal Reserve Bank of New York.

Bakker BB, Klingen C (2012): How Emerging Europe Came Through the 2008/09 Crisis. An Account by the Staff of the IMF's European Department. International Monetary Fund, Washington, DC.

BCBS (2013): Global Systemically Important Banks: Updated Assessment Methodology and the Higher Loss Absorbency Requirement. Basel Committee on Banking Supervision.

Beck T, De Jonghe O, Schepens G (2013): Bank Competition and Stability: Cross-Country Heterogeneity. Journal of Financial Intermediation, 22:218-244.

Behr P, Schmidt RH, Xie R (2010): Market Structure, Capital Regulation and Bank Risk Taking. Journal of Financial Services Research, 37:131-158.

Beltratti A, Stulz R (2012): The Credit Crisis Around the Globe: Why Did Some Banks Perform Better? Journal of Financial Economics, 105:1-17.

Berger AN, DeYoung, R, Flannery MJ, Lee DK, Öztekin Ö (2008): How Do Large Banking Organizations Manage Their Capital Ratios? Journal of Financial Services Research, 34(2-3):123149.

BIS (2012): Operationalising the Selection and Application of Macroprudential Instruments. Committee on the Global Financial System.

Black L, Correa R, Huang X, Zhou H (2016): The Systemic Risk of European Banks During the Financial and Sovereign Debt Crises. Journal of Banking Finance, 63:107-125.

Bluhm M, Krahnen JP (2014): Systemic Risk in an Interconnected Banking System with Endogenous Assets Markets. Journal of Financial Stability, 13:75-94.

Bouvatier V, Lepetit L (2012): Provisioning Rules and Bank Lending: A Theoretical Model. Journal of Financial Stability, 8:25-31.

Bridges J, Nielsen M, Radia A, Gregory D, Pezzini S, Spaltro M (2015): The Impact of Capital Requirements on Bank Lending. Bank of England Working Paper, No. 486. 
Brown CO, Dinc S (2009): Too Many to Fail? Evidence of Regulatory Forbearance When the Banking Sectori is Weak. Review of Financial Studies, 24(4):1378-1405.

Brunnermeier MK, Dong G, Palia D (2012): Banks' Non-Interest Income and Systemic Risk. AFA 2012 Chicago Meetings Paper.

Bruno V, Shim I, Shin SH (2016): Comparative Assessment of Macroprudential Policies. Journal of Financial Stability, 28:183-202.

Bui C, Scheule H, Wu E (2017): The Value of Bank Capital Buffers in Maintaining Financial System Resilience. Journal of Financial Stability, 33:23-40.

Bustamante C, Hamann F (2015): Countercyclical Reserve Requirements in a Heterogeneous-Agent and Incomplete Financial Markets Economy. Journal of Macroeconomics, 46:66-70.

Cerutti E, Claessens S, Laeven L (2017a): The Use and Effectiveness of Macroprudential Policies: New Evidence. Journal of Financial Stability, 28:203-224.

Cerutti E, Correa R, Fiorentino E, Segalla E (2017b): Changes in Prudential Policy Instruments - A new Cross-Country Database. International Journal of Central Banking, 13(1):477-503.

Cizel J, Frost J, Houben APW (2016): Effective Macroprudential Policy: Cross-Sector Subtitution from Price and Quantity Measures. IMF Working Paper, WP/16/94

Claessens S, Ghosh SR, Mihet R (2013): Macro - Prudential Policies to Mitigate Financial System Vulnerabilities. Journal of International Money and Finance, 39:153-185.

Corrado L, Schuler T (2017). Interbank Market Failure and Macro-Prudential Policies. Journal of Financial Stability, 33:133-149.

Dagher J, Dell'Ariccia G, Laeven L, Ratnovski L, Tong H (2016): Benefits and Costs of Bank Capital. IMF Staff Discussion, SDN/16/04.

Danielsson J, Shin SH, Zigrand J (2013): Endogenous and Systemic Risk. In: Haubrich J, Lo A (eds): Quantifying Systemic Risk. University of Chicago Press, Chicago, 73-94.

Dell'Ariccia G, Igan D, Laeven L, Tong H, Bakker B, Vandenbussche J (2012): Policies for Macrofinancial Stability: How to Deal with Credit Booms. International Monetary Fund Staff Discussion Notes, No. 12/06

Dermine J, Schoenmaker D (2010): In Banking, is Small Beautiful? Financial Markets, Institutions and Instruments, 19:1-19.

Dimova D, Kongsamut P, Vandenbussche J (2016): Macroprudential Policies in Southeastern Europe. IMF Working Paper, No. 16/29.

Duan J, Sun J, Wang T (2012): Multiperiod Corporate Default Predictions - A Forward Intensity Approach. Journal of Econometrics, 170(1)191-209.

Duan J.-C, Wang T (2012): Measuring Distance-to-Default for Financial and Non-Financial Firms. Global Credit Review, 2:95-108.

EP (2016): Global Systemically Important Banks in Europe. European Parliament.

ESRB (2014): The ESRB Handbook on Operationalising Macro-prudential Policy in the Banking Sector. European Sytemic Risk Board.

Floreani J, Polato M, Paltrinieri A, Pichler F (2015): Credit Quality, Bank Provisioning and Systematic Risk in Banking Business. In: Beccalli E, Poli F (eds): Bank Risk, Governance and Regulation, Palgrave Macmillan, UK, 1-34.

FSB (2016): 2016 list of global systemically important banks (G-SIBs). Financial Stability Board.

Fungacova Z, Nuutilainen R, Weill L (2016): Reserve Requirements and the Bank Lending Channel in China. Journal of Macroeconomics, 50:37-50.

Gauthies C, Lehar A, Souissi M (2012): Macroprudential Capital Requirements and Systemic Risk. Journal of Financial Intermediation, 21:594-618.

Hallissey N, Kelly R, O'Malley T (2014): Macro-prudential Tools and Credit Risk of Property Lending at Irish banks. Central Bank of Ireland, Economic Letters, 10/EL/14. 
Hanson SC, Kashyap AK, Stein, JC (2011): A Macroprudential Approach to Financial Regulation. Journal of Economic Perspectives, 25(1):3-28.

IMF (2013): Key Aspects of Macroprudential Policy. International Monetary Fund.

IMF (2013): The Interaction of Monetary and Macroprudential Policies, Backgroup paper. International Moetary Fund.

Jimenez G, Lopez JA, Saurina J (2013): How Does Competition Affect Bank Risk-Taking. Journal of Financial Stability, 9:185-195.

Jorion P (1997): Value-at-Risk: The New Benchmark for Controlling Market Risk. McGraw-Hill, Irwin, Chicago, Ill.

Kuttner K, Shim I (2016): Can Non-Interest Rate Policies Stabilize Housing Markets? Evidence from a Panel of 57 Economies. Journal of Financial Stability, 26:31-44.

Laeven L, Ratnovsky L, Tong H (2016): Bank Size, Capital, and Systemic Risk: Some International Evidence. Journal of Banking and Finance, 69(S1):S25-S34.

Lim C, Columba F, Costa A, Kongsamut P, Otani A, Saiyid M, Wezel T, Wu X (2011): Macroprudential Policy: What Instruments and How to Use Them? Lessons from Country Experiences. IMF Working Paper, WP/11/238

López-Espinosa G, Moreno AR., Valderrama L (2012): Short-Term Wholesale Funding and Systemic Risk: A Global CoVaR Approach. Journal of Banking and Finance, 36(12):3150-3162.

Maddaloni A, Peydro JL (2013): Monetary Policy, Macroprudential Policy and Banking Stability. Evidence from the Euro Area. International Journal of Central Banking, 9(1):121-169.

Mayordomo S, Rogriques-Moreno M, Pena JI (2014): Derivatives Holdings and Systemic Risk in the U.S. Banking Sector. Journal of Banking Finance, 45:84-104.

Nijskens R, Wagner W (2011): Credit Risk Transfer Activities and Systemic Risk: How Banks Become less Risky Individually but Posed Greater Risks to the Financial System at the Same Time. Journal of Banking Finance, 35:1391-1398.

Noss J, Toffano P (2016): Estimating the Impact of Changes in Aggregate Bank Capital Requirements During an Upswing. Journal of Banking Finance, 62:15-27.

Osinski J, Seal K, Hoogduin L (2013): Macroprudential and Microprudential Policies: Toward Cohabitation. IMF Staff Discussion Note, No. 13/05.

Perotti E, Ratnovski L, Vlahu R (2011): Capital Regulation and Tail Risk. International Journal of Central Banking 7(4):123-163.

Tarashev N, Borio C, Tsatsaronis K (2010): Attributing Systemic Risk to Individual Institutions. BIS Working Paper, No. 308.

Thakor AV (2014): Bank Capital and Financial Stability: An Economic Trade-Off or a Faustian Bargain. Annual Review of Financial Economics, 6:185-223.

Vallascas F, Keasey K (2012): Bank Resilience to Systemic Shocks and the Stability of Banking Systems: Small is Beautiful. Journal of International Money and Finance, 31:1745-1776.

Van Oordt M, Zhou C (2015): Systemic Risk of European Bank: Regulators and Markets. DNB Working Paper, No. 478.

Vandenbussche J, Vogel U, Detragiache E (2015): Macroprudential Policies and Housing Prices: A New Database and Empirical Evidence for Central, Eastern and Southeastern Europe. Journal of Money, Credit and Banking, 47(1):343-377.

Wei $\beta$ GN, Bostandzic D, Neuman S (2014): What Factors Drive Systemic Risk During International Financial Crises? Journal of Banking and Finance, 41:78-96.

Wong E, Fong T, Choi H (2011): Procyclicality of Loan-Loss Provisionong and Systemic Risk in the Hong Kong Banking System. Hong Kong Monetary Authority Quarterly Bulletin, 1-13.

Yesin P (2013): Foreign Currency Loans and Systemic Risk in Europe. Federal Reserve Bank of St. Louis Review, 95(3):219-235. 